\title{
Low assimilate partitioning to root biomass is associated with carbon losses at an intensively managed temperate grassland
}

\author{
Arne Poyda $(\mathbb{D})$ Thorsten Reinsch • Inger J. Struck • \\ R. Howard Skinner • Christof Kluß • Friedhelm Taube
}

Received: 7 May 2020 / Accepted: 16 November 2020 / Published online: 26 November 2020

(C) The Author(s) 2020

\begin{abstract}
Aims This study aimed to investigate how efficiently assimilated carbon (C) is incorporated in plant biomass at an intensively managed old permanent grassland, how $\mathrm{C}$ is partitioned between shoots and roots and what are the implications for $\mathrm{C}$ sequestration.

Methods Using the eddy covariance technique, the atmosphere-biosphere exchange of $\mathrm{CO}_{2}$ was measured for two years at a sandy grassland site in northern Germany. In addition to aboveground net primary production (ANPP), belowground NPP (BNPP) was observed using the ingrowth core method.

Results The grassland showed a high productivity in terms of biomass yield (14.8 Mg dry matter $\mathrm{ha}^{-1} \mathrm{yr}^{-1}$ ) and net $\mathrm{CO}_{2}$ uptake $\left(-2.82 \mathrm{Mg} \mathrm{CO}_{2}-\mathrm{C} \mathrm{ha}^{-1} \mathrm{yr}^{-1}\right)$. Photosynthetically assimilated $\mathrm{C}$ was converted to biomass with a high carbon use efficiency (CUE) of $71 \%$ during
\end{abstract}

Responsible Editor: Elizabeth M Baggs.

A. Poyda $(\bowtie) \cdot$ T. Reinsch • I. J. Struck • C. Kluß •

F. Taube

Institute of Crop Science and Plant Breeding, Grass and Forage

Science/Organic Agriculture, Kiel University,

Hermann-Rodewald-Str. 9, 24118 Kiel, Germany

e-mail: apoyda@gfo.uni-kiel.de

R. H. Skinner

USDA-ARS, Pasture Systems and Watershed Management

Research Unit, Building 3702, Curtin Road, University Park, PA 16802, USA

F. Taube

Grass Based Dairy Systems, Animal Production Systems Group, Wageningen University (WUR), Wageningen, The Netherlands the growing season. However, a comparably low fraction of $17 \%$ of NPP was allocated to roots $\left(f_{B N P P}\right)$. Consequently, the main fraction of NPP was removed during harvest, turning the site into a net source of $0.29 \mathrm{Mg} \mathrm{Cha}^{-1} \mathrm{yr}^{-1}$.

Conclusions Our study showed the flexibility of grass root growth patterns in response to alterations in resource availability. We conclude that highly fertilized grasslands can lose their ability for $\mathrm{C}$ sequestration due to low belowground $\mathrm{C}$ allocation.

Keywords Carbon partitioning · Plant carbon use efficiency $\cdot$ Root growth $\cdot$ Eddy covariance $\cdot$ Permanent grasslands $\cdot$ Black sands $\cdot$ Carbon equilibrium

$\begin{array}{ll}\text { Abbreviations } \\ \text { AGB } & \text { Aboveground biomass } \\ \text { AGC } & \text { Automatic gain control } \\ \text { ANPP } & \text { Aboveground net primary production } \\ \text { BGB } & \text { Belowground biomass } \\ \text { BNPP } & \text { Belowground net primary production } \\ \text { CAN } & \text { Calcium ammonium nitrate } \\ \text { CUE } & \text { Carbon use efficiency } \\ \text { EBR } & \text { Energy balance ratio } \\ \text { EC } & \text { Eddy covariance } \\ f_{\text {BNPP }} & \text { Fraction of belowground net primary } \\ & \text { production on NPP } \\ \text { G } & \text { Ground heat flux } \\ \text { GPP } & \text { Gross primary production } \\ \text { GWL } & \text { Groundwater level } \\ \text { H } & \text { Sensible heat } \\ \text { IRGA } & \text { Infrared gas analyzer }\end{array}$




$\begin{array}{ll}\text { LE } & \text { Latent heat of vaporization } \\ \text { NBP } & \text { Net biome productivity } \\ \text { NEE } & \text { Net ecosystem exchange } \\ \text { NPP } & \text { Net primary production } \\ \text { POM } & \text { Particulate organic matter } \\ \mathrm{R}_{\mathrm{a}} & \text { Autotrophic respiration } \\ \mathrm{R}_{\mathrm{ECO}} & \text { Ecosystem respiration } \\ \text { RFT } & \text { Root functional traits } \\ \mathrm{R}_{\mathrm{h}} & \text { Heterotrophic respiration } \\ \mathrm{RLD} & \text { Root length density } \\ \mathrm{R}_{\mathrm{n}} & \text { Net radiation } \\ \text { SOC } & \text { Soil organic carbon } \\ \text { SOM } & \text { Soil organic matter } \\ \text { SRL } & \text { Specific root length }\end{array}$

\section{Introduction}

Permanent grasslands cover about one third (34\%) of the utilized agricultural area in EU-28 (Coyette and Schenk 2013). In the temperate zone, grasslands represent a highly productive feed source for livestock production (Hopkins 2000), particularly for dairy cattle. Besides its agricultural importance, grasslands act as significant sinks for atmospheric carbon dioxide $\left(\mathrm{CO}_{2}\right)$ with a potential $\mathrm{CO}_{2}$ uptake capacity larger than forest ecosystems (Gilmanov et al. 2010). Compared to annual crops, larger fractions of assimilated $\mathrm{C}$ are allocated to roots under perennial grassland vegetation, thus the conversion of croplands to permanent grasslands is among the most effective measures for greenhouse gas (GHG) mitigation in agriculture (Smith et al. 2008; Soussana et al. 2010). Accordingly, the German Agricultural Soil Inventory documented that mean soil organic carbon (SOC) contents in German grassland soils are more than twice as high as cropland SOC contents (Vos et al. 2018).

Micrometeorological methods (e.g. Baldocchi et al. 1988) have been applied in numerous investigations to estimate the exchange of $\mathrm{CO}_{2}$ and other trace gases, water vapor and energy between ecosystems and the atmosphere. For the micrometeorological eddy covariance (EC) method, flux networks, covering ecosystems and climate zones all over the world (Dolman et al. 2008), were developed to determine the exchange of carbon (FLUXNET, Baldocchi et al. 2001) or nitrogen (NitroEurope, Skiba et al. 2009). Data on net ecosystem exchange (NEE) of $\mathrm{CO}_{2}$ obtained by EC measurements on grassland sites in Europe showed uptakes of up to -6.5 and losses up to $1.7 \mathrm{MgC} \mathrm{ha}^{-1} \mathrm{yr}^{-1}$, with most sites $\mathrm{CO}_{2}$ sinks. Net $\mathrm{CO}_{2}$ losses were associated with organic soils, over-grazing and heat stress (Gilmanov et al. 2007).

The fraction of assimilated $\mathrm{C}$ that can be recovered in grassland biomass (i.e., the carbon use efficiency (CUE) of the grassland plants) might vary in a wide range between 0.32 and 0.88 (Riederer et al. 2015). Thereby, the CUE increases with better availability of belowground resources as shown by Saliendra et al. (2018) in a semiarid environment. Grasses are able to cope with changing belowground resource availabilities by adapting the production and specific length (i.e., thickness) of roots (James et al. 2010). According to the functional equilibrium theory (Brouwer 1963), a decrease in belowground resource availability will enhance the fraction of belowground allocated photoassimilates used for root growth. Evidence for this mechanism was documented for grasslands in a semiarid environment by Li et al. (2011). A high percentage of the belowground allocated $\mathrm{C}$, however, is released into the soil as labile organic compounds (rhizodeposition), which are rapidly utilized by microorganisms (Hütsch et al. 2002). Productive grass species such as perennial ryegrass (Lolium perenne) might translocate high amounts of organic $\mathrm{C}$, with a magnitude of up to $2.8 \mathrm{Mg} \mathrm{C} \mathrm{ha}^{-1}$, into the soil during a single vegetation period (Domanski et al. 2001; Kuzyakov et al. 2001).

As postulated by Cotrufo et al. (2013), labile plant constituents are the main source for the formation of stable SOM. This hypothesis is based on the higher microbial substrate use efficiency of labile compounds and their relative dominance in microbial products with strong chemical bonding to the mineral soil matrix. As this chemical stabilization of SOM is mainly located on the clay fraction, the $\mathrm{C}$ sequestration potential generally increases with clay content (Hütsch et al. 2002). Furthermore, the finest mineral particle fractions (clay + fine silt) determine the physical protection of SOM through aggregation processes and the formation of microaggregates within macroaggregates (Six and Paustian 2014).

In contrast to the described mechanisms, high SOC contents can also be found in sandy soils of northwestern Europe that are poor in clay. These so-called "black sands" are often found at sites of former heathland vegetation and their SOC stocks have a stable chemical composition mainly present in particulate organic matter 
(POM) as the stabilization capacity on mineral surfaces is very low (Vos et al. 2018). In northern Germany, high $\mathrm{C}$ losses have been observed for grasslands on organic soils (Poyda et al. 2016) but there is a lack of information on the $\mathrm{C}$ budgets of grassland on $\mathrm{C}$-rich mineral soils such as black sands.

Depending on their sward age, $\mathrm{C}$ sequestration potential and management intensity, permanent grasslands do not necessarily act as $\mathrm{C}$ sinks. The $\mathrm{C}$ sequestration potential describes that $\mathrm{C}$ accumulation is a non-linear process and tends towards an equilibrium of humification and decomposition. This potential depends on site properties and initial $\mathrm{C}$ content, and the sward age when an equilibrium is reached might be $>120 \mathrm{yr}$ (Poeplau et al. 2011). As high amounts of fixed $C$ during net primary production (NPP) of plants can be removed from grasslands through cutting or livestock grazing and are only partly returned as manure, slurry or excreta, grasslands that were intensively managed over decades have been reported to act as net $\mathrm{C}$ sources (Skinner 2008, 2013; Soussana et al. 2010). Even though several studies have focused on the effects of grassland management on $\mathrm{C}$ sequestration, there is a lack of data regarding the efficiency of converting photosynthetically fixed $\mathrm{C}$ to plant tissue and the partitioning of this assimilated $\mathrm{C}$ between shoots and roots. Furthermore, knowledge related to the temporal dynamics of the plant CUE and allocation in grassland swards as well as its relationships with environmental effects under field conditions is still scarce.

In this study, $\mathrm{CO}_{2}$ fluxes measured by the $\mathrm{EC}$ technique as well as above- and belowground productivity were determined at an intensively managed old permanent grassland site on a sandy and C-rich soil in northern Germany. Root samples were analyzed for specific functional traits such as root length density and specific root length. By the combination of these different measurements, the following hypotheses $(\mathrm{H})$ will be tested:

H1: Due to high resource availability, intensively managed temperate grasslands are able to convert the photosynthetically fixed $\mathrm{C}$ to plant biomass with high efficiency.

1 The fraction of assimilated $\mathrm{C}$ allocated to root biomass is higher at lower belowground resource availability and due to high fertilization rates, the $\mathrm{C}$ partitioning at the study site is mainly affected by water availability.
2 Due to its sandy texture and the long-term intensive management, the SOC stock of the study site is at an equilibrium state.

\section{Material and methods}

\section{Study periods}

This study was conducted during the years 2012-2014. However, the different measurements were not consistently applied over the full experimental period. $\mathrm{CO}_{2}$ flux measurements covered a period of two full years from 1 August 2012-31 July 2014. Harvest yields will therefore be related to these two years as well. In contrast, measurements of total aboveground (including stubbles) and belowground productivity were measured from 29 October 2013-8 October 2014. Six intervals were defined to determine the productivity during the non-growing season (29 October 2013-14 January 2014 and 15 January - 1 April 2014) and the four growth periods in 2014 (2 April - 20 May, 21 May - 4 July, 5 July -7 August and 8 August -8 October). In the following, these intervals will be referred to as I1 - I6.

\section{Study area}

The investigated grassland site with a size of 4.4 ha is situated in a lowland area in the federal state of Schleswig-Holstein, northern Germany at $54.3^{\circ} \mathrm{N}, 9.5^{\circ} \mathrm{E}$. The study area is located close to the coasts of North Sea $(45 \mathrm{~km})$ and Baltic Sea $(25 \mathrm{~km})$ and therefore characterized by a maritime temperate climate. For the period 1981-2010, the closest meteorological station of Germany's National Meteorological Service (DWD) $(5 \mathrm{~km})$ showed a mean annual temperature of $8.6^{\circ} \mathrm{C}$ and a mean annual precipitation of $814 \mathrm{~mm}$. Soil formation in the region took place in consequence of glacial melting at the end of the last ice age (Weichsel glacial stage). Meltwater deposits of the glacial outwash plains formed the parent material for pedogenesis. In the lower western parts of these plains, the meltwater sands are often overlain by eolian sands, deposited during the late-glacial stage (Blume and Brümmer 1986).

Due to poor soil quality, the region is not suitable for arable cash crop production and has traditionally been utilized as grassland for forage production in dairy farms. In recent decades, dairy production systems experienced 
an ongoing intensification. In the study area, this resulted in grassland conversion for silage maize production and intensification of the remaining grassland to ensure high forage yields. The study site has been used as a grassland without interruption or renovation of the sward since many decades ( $>40 \mathrm{yr}$ ) and was utilized conventionally and with high intensity, including mineral and organic fertilization. According to WRB (2015), the soil type of the study site was classified as Humic Podzol. The vegetation composition at the site was dominated by perennial ryegrass (Lolium perenne), the typical grass for intensive grasslands of the temperate zone ensuring high forage quality (HoPKINS 2000). However, unsown grass species potentially reflect the specific conditions at the study site. Thus, relatively high proportions of cough grass (Elymus repens) and orchard grass (Dactylis glomerata) might indicate a periodically low water availability (Table 1).
During the period 2012-2014, the site was cut three times per year and subsequently grazed by dairy cattle for 2-3 weeks in autumn. Cattle slurry was deployed in early spring and after each defoliation with decreasing amounts. Around the same dates as slurry application, mineral $\mathrm{N}$ was fertilized as calcium ammonium nitrate (CAN). On average, the ratio of total slurry $\mathrm{N}$ to mineral fertilizer $\mathrm{N}$ applied was almost balanced (1.02) with a total $\mathrm{N}$ fertilization rate of $465 \mathrm{~kg} \mathrm{~N} \mathrm{ha}^{-1} \mathrm{yr}^{-1}$ on average over the study period (Table 1).

Site characteristics

\section{Weather}

Meteorological data was collected at the eddy covariance (EC) station in the center of the study site.

Table 1 Soil and land use characterization of the study site

\begin{tabular}{|c|c|c|}
\hline \multicolumn{2}{|l|}{ Property } & \multirow{2}{*}{$\begin{array}{l}\text { Value } \\
93.7(1.7) / 3.1(0.6) / 3.2(0.2)\end{array}$} \\
\hline Sand / Silt / Clay $(\%)^{\mathrm{ac}}$ & & \\
\hline $\operatorname{SOC}(\%)^{\mathrm{ab}}$ & & $4.1(1.0)$ \\
\hline $\mathrm{C} / \mathrm{N}^{\mathrm{ab}}$ & & $15.8(0.6)$ \\
\hline Bulk density $\left(\mathrm{g} \mathrm{cm}^{-3}\right)^{\mathrm{ac}}$ & & $1.41(0.01)$ \\
\hline $\mathrm{C}$ stock $\left(\mathrm{Mg} \mathrm{ha}^{-1}\right)^{\mathrm{ac}}$ & & $174(1)$ \\
\hline $\mathrm{pH}\left(\mathrm{CaCl}_{2}\right)^{\mathrm{ad}}$ & & $4.93(0.15)$ \\
\hline $\mathrm{P}_{2} \mathrm{O}_{5}\left(\mathrm{mg} 100 \mathrm{~g}^{-1}\right)^{\mathrm{ad}}$ & & $14.6(4.9)$ \\
\hline $\mathrm{K}_{2} \mathrm{O}\left(\mathrm{mg} 100 \mathrm{~g}^{-1}\right)^{\mathrm{ad}}$ & & $3.1(1.3)$ \\
\hline $\operatorname{Mg}\left(\operatorname{mg~} 100 \mathrm{~g}^{-1}\right)^{\mathrm{ad}}$ & & $10.1(2.0)$ \\
\hline Groundwater level ( $\mathrm{cm}$ below surface $)^{\mathrm{e}}$ & & $118(21)$ \\
\hline $\mathrm{N}$ fertilization $\left(\mathrm{kg} \mathrm{N} \mathrm{ha}^{-1} \mathrm{yr}^{-1}\right)^{\mathrm{f}}$ & & $465(517,501,377)$ \\
\hline \multirow[t]{3}{*}{ Grassland cuttings } & 2012 & 20 May, 2 Jul, 14 Aug \\
\hline & 2013 & 31 May, 14 Jul, 30 Aug \\
\hline & 2014 & 15 May, 25 Jun, 7 Aug \\
\hline \multirow[t]{3}{*}{ Grazing } & 2012 & 23 Sep -9 Oct \\
\hline & 2013 & 3 Oct -25 Oct \\
\hline & 2014 & 8 Oct -27 Oct \\
\hline Main plant species (\%) & & $\begin{array}{l}\text { Perennial ryegrass (Lolium perenne): } 59 \\
\text { Couch grass (Elymus repens): } 29 \\
\text { Orchard grass (Dactylis glomerata): } 4 \\
\text { Common dandelion (Taraxacum officinale) } 4 \\
\text { White clover (Trifolium repens) } 3\end{array}$ \\
\hline
\end{tabular}

\footnotetext{
${ }^{a}$ Values are for the $0-30 \mathrm{~cm}$ soil depth. ${ }^{\mathrm{b}}$ Mean value and standard deviation from biannual samplings during the period October $2012-$ March $2014(n=4) .{ }^{\mathrm{c}}$ Mean value and standard deviation of soil samples taken in May $2013(n=4) .{ }^{\mathrm{d}}$ Mean values and standard deviation of samples taken in March 2013 and July $2014(n=8)$. ${ }^{\mathrm{e}}$ Mean value and standard deviation of linear interpolated weekly measurements during the period July 2012 - July 2014 . ${ }^{\mathrm{f}}$ Mean annual sum of applied nitrogen from organic and mineral fertilizers during the study period (20122014) and the amounts for the respective years (in brackets)
} 
Measurements covered air temperature and relative humidity in $2 \mathrm{~m}$ height (HMP45C temperature and $\mathrm{RH}$ probe, Vaisala, Woburn, MA, USA), precipitation in $1 \mathrm{~m}$ height (TE525 tipping bucket rain gauge, Texas Electronics, Dallas, TX, USA), net radiation roughly $1.7 \mathrm{~m}$ above canopy (Q7.1-L net radiometer, Campbell Scientific Inc., Logan, UT, USA) and photosynthetic active radiation in $3 \mathrm{~m}$ height (190SZ quantum sensor, Li-COR Biosciences, Lincoln, NE, USA). Data was stored on a CR5000 data logger (Campbell Scientific Inc., Logan, UT, USA).

\section{Groundwater and soil}

For the monitoring of groundwater level (GWL), a perforated PVC tube $(\mathrm{d}=5 \mathrm{~cm}, 1=200 \mathrm{~cm})$ was inserted into the ground. The GWL was recorded manually with a minimum of one GWL record per week. For the calculation of annual mean values, the recorded GWLs were linear interpolated to avoid overestimation of periods with more frequent measurements.

Soil samples were taken fortnightly at three consistent spots around the EC station and a depth of 0-20 cm using a soil auger. The gravimetric water content of soil samples was obtained by oven drying at $105^{\circ} \mathrm{C}$ until constant weight. Soil volumetric water content was estimated by multiplying with dry bulk density, which was determined according to DIN ISO 11272 (HBU 1998). Contents of SOC and total $\mathrm{N}$ were analyzed for the depths of 0-30, 30-60 and 60-90 cm with an elemental analyzer (Vario Max CN, Elementar, Hanau, Germany). The soil $\mathrm{pH}$ was determined in the laboratories of the AGROLAB Group according to VDLUFA (1991) for samples of 0-30 cm soil depth. At the EC station, soil temperature in $5 \mathrm{~cm}$ (Campbell Scientific Model 107 soil temperature probe) and soil moisture (Campbell Scientific CS616 water content reflectometer) in 5 and $30 \mathrm{~cm}$ were recorded in 20 min intervals.

Vegetation measurements

\section{Aboveground biomass}

The sward composition as well as the relative abundance of species was determined according to Klapp and Stählin (1936) in August 2014. To quantify the total harvestable biomass, vegetation above a height of $5 \mathrm{~cm}$ was manually sampled at three consistent positions of $0.25 \mathrm{~m}^{2}$ around the EC station at the times of grassland cuttings. During periods of grazing, three exclosures of roughly $25 \mathrm{~m}^{2}$ were installed to determine the amount of aboveground biomass (AGB) before and the growth rate during grazing. After a grazing period, the remaining biomass was determined at the grazed area to estimate the pasture yield. During I1 - I6, the total AGB including non-harvestable stubble and litter biomass was sampled with nine replicates. The dry matter content of all AGB samples was determined after oven drying at $60{ }^{\circ} \mathrm{C}$ until constant weight. Subsequently, the material was milled to a particle size of $1 \mathrm{~mm}$ using a centrifugal mill (Cyclotech mill, Tecator, Foss, Hillerød, Denmark) and the $\mathrm{C}$ and $\mathrm{N}$ concentrations were measured using the elemental analyzer.

\section{Belowground biomass}

To quantify the net root growth of the grassland sward during I1 - I6, the ingrowth core method (Steingrobe et al. 2000) was used. The ingrowth cores were installed at nine equidistant positions around the EC station and at an angle of $45^{\circ}$ to a vertical depth of $30 \mathrm{~cm}$ using a spiral hand auger (Eijkelkamp Soil \& Water, Giesbeek, The Netherlands). We followed the procedure as described in detail by Chen et al. (2015). The accumulated root biomass over a certain period was defined as the belowground net primary production (BNPP). In combination with the simultaneously measured aboveground net primary production (ANPP), total net primary production $(\mathrm{NPP}=\mathrm{ANPP}+\mathrm{BNPP})$ as well as the fraction of BNPP on total NPP $\left(\mathrm{f}_{\mathrm{BNPP}}\right)$ was calculated:

$$
f_{B N P P}=\frac{\mathrm{BNPP}}{\mathrm{ANPP}+\mathrm{BNPP}}
$$

To quantify the total length of roots within the ingrowth cores, the intersection method as proposed by Tennant (1975) and applied by Chen et al. (2016) was used. When the total root length of the ingrowth core $\left(\mathrm{RL}_{\mathrm{IC}}, \mathrm{cm}\right)$ was determined, root functional traits (RFT) such as the root length density (RLD) and the specific root length (SRL) were calculated from the volume of the ingrowth core $\left(\mathrm{V}_{\mathrm{IC}}=534 \mathrm{~cm}^{3}\right)$ and the total fresh root mass within the ingrowth core $\left(\mathrm{m}_{\mathrm{r}_{-} \mathrm{IC}}, \mathrm{g}\right)$, respectively.

$$
R L D=\frac{\mathrm{RL}_{I C}}{\mathrm{~V}_{I C}}
$$


$S R L=\frac{\mathrm{RL}_{I C}}{\mathrm{~m}_{r-I C}}$

$\mathrm{CO}_{2}$ exchange

\section{Flux measurements and data processing}

The micrometeorological eddy covariance (EC) technique was used to estimate the $\mathrm{CO}_{2}$ exchange between the grassland ecosystem and the atmosphere. The EC system was equipped with a LI-7500 open path $\mathrm{CO}_{2} /$ $\mathrm{H}_{2} \mathrm{O}$ infrared gas analyzer (IRGA; LI-COR Biosciences, Lincoln, NE, USA) and a CSAT3 3-D sonic anemometer (Campbell Scientific Inc., Logan, UT, USA), installed at a height of $1.75 \mathrm{~m}$ above the ground. Data was collected at $10 \mathrm{~Hz}$ and stored on a CR5000 data logger (Campbell Scientific Inc., Logan, UT, USA). The EC system was set up in the center of the study site and powered by $12 \mathrm{~V}$ marine batteries that were charged by two $64 \mathrm{~W}$ solar panels.

Raw data was processed with the software package TK3.1 (Mauder et al. 2013) to compute the $\mathrm{CO}_{2}$ fluxes for 30-min intervals. By using this software, spike detection (Vickers and Mahrt 1997), planar fit coordinate rotation (Wilczak et al. 2001), correction of spectral loss (Moore 1986), conversion of sonic temperature into actual temperature (Schotanus et al. 1983) as well as correction for density fluctuations and vertical mass transport (Webb et al. 1980) were applied to the data.

\section{Flux filtering and quality control}

Quality classification of computed flux values followed the nine class flagging scheme of Foken et al. (2004). To remove inaccurate and unreliable data from the dataset, a three-step filtering approach was applied. Firstly, data flagged $>6$ (7-9) was discarded and secondly, flux values with an associated automatic gain control (AGC) value $>56$ were filtered out. The AGC is an indicator for pollution of the focus lens of the IRGA. As described by Schmidt et al. (2012), inaccuracies of the IRGA can be identified by comparing measurements of absolute humidity at the combined temperature and humidity probe with those at the IRGA. At AGC $>56$, absolute differences as well as the variability of differences strongly increased with IRGA measurements mainly underestimating absolute humidity. As a third step, a median filter was used for the remaining data (Demyan et al. 2016; Poyda et al. 2019). Thereby, fluxes that were 6-times greater than the median of the absolute flux values of the previous four days were removed.

As a standard quality criterion for EC measurements, the energy balance ratio (EBR) was calculated for every time step with available high quality data as follows:

$E B R=\frac{\mathrm{H}+\mathrm{LE}}{\mathrm{R}_{n}-\mathrm{G}}$

where $\mathrm{H}$ and $\mathrm{LE}$ are the turbulent fluxes of sensible and latent heat, respectively, and the difference between net radiation $\left(R_{n}\right)$ and ground heat flux $(G)$ is the available energy, with all units in $\mathrm{W} \mathrm{m}^{-2}$. As described in detail by Eshonkulov et al. (2019), G was calculated calorimetrically as the sum of the mean measured soil heat flux at $8 \mathrm{~cm}$ soil depth (2 HFT3-L, Campbell Scientific Inc., Logan, UT, USA) and the calculated soil heat storage in the soil layer above the heat flux plates. The uncertainty of computed turbulent fluxes was obtained as the sum of the random error and the instrumental noise calculated by the TK3.1 software.

\section{Gap filling and flux partitioning}

In order to calculate budgets of NEE, ecosystem respiration $\left(\mathrm{R}_{\mathrm{ECO}}\right)$ and gross primary production (GPP) for certain periods, missing values of NEE were filled and the gap-filled NEE was partitioned into $\mathrm{R}_{\mathrm{ECO}}$ and GPP both by using the REddyProc web application (Wutzler et al. 2018). For details on the gap-filling process, the reader is referred to Poyda et al. (2019). The nighttimebased approach of Reichstein et al. (2005) was used to partition NEE into $\mathrm{R}_{\mathrm{ECO}}$ and GPP fitting the Lloyd and Taylor (1994) model to the dataset of nighttime NEE (global radiation $<10 \mathrm{~W} \mathrm{~m}^{-2}$ ) versus air temperature for four-day intervals and calculating GPP as the difference between gap-filled NEE and estimated $\mathrm{R}_{\mathrm{ECO}}$.

\section{Net biome productivity}

To calculate full annual $\mathrm{C}$ budgets, all relevant $\mathrm{C}$ fluxes at the field-scale have to be considered. As losses via dissolved organic carbon were not captured in this study and the $\mathrm{C}$ exchange as $\mathrm{CH}_{4}$, which was measured using manual chambers, was on a negligible level (mean annual uptake of $0.32 \mathrm{~kg} \mathrm{CH}_{4}-\mathrm{C} \mathrm{ha}^{-1} \mathrm{yr}^{-1}$ ), the net 
biome productivity (NBP) was calculated as follows:

$N B P=N E E+C_{i n}+C_{e x}$

where NEE is the cumulative gap-filled net ecosystem exchange for a certain period $\left(\mathrm{kg} \mathrm{CO}_{2}-\mathrm{C} \mathrm{ha}^{-1}\right), \mathrm{C}_{\text {in }}$ is the $\mathrm{C}$ input by slurry application and excreta from grazing cattle $\left(\mathrm{kg} \mathrm{C} \mathrm{ha}^{-1}\right)$, and $\mathrm{C}_{\mathrm{ex}}$ is the $\mathrm{C}$ export by grassland harvest and grazing cattle $\left(\mathrm{kg} \mathrm{C} \mathrm{ha}^{-1}\right)$. The amount of $\mathrm{C}$ input via organic fertilization with cattle slurry was calculated from the total amounts of applied slurry $\left(\mathrm{m}^{3} \mathrm{ha}^{-1}\right)$ reported by the farmer and the mean $\mathrm{C}$ concentration in fresh slurry $\left(45.6 \mathrm{~kg} \mathrm{C} \mathrm{m}^{-3}\right)$ as measured using the elemental analyzer. According to Skinner (2013), it was additionally considered that during grazing, cattle returned $37 \%$ of consumed biomass to the site as excreta, which was based on digestibility results of Soder et al. (2006). $\mathrm{C}_{\mathrm{ex}}$ was derived from manual samplings of harvestable and grazed biomass and the respective $\mathrm{C}$ concentrations.

Plant carbon use efficiency and carbon residual.

Partitioned GPP and $\mathrm{R}_{\mathrm{ECO}}$ were cumulated for I1 - I5 as EC measurements as well as ANPP and BNPP were available for this period. The plant carbon use efficiency (CUE) was calculated for each interval as the fraction of GPP converted to biomass C (Waring et al. 1998):

$C U E=\frac{A N P P+B N P P}{G P P}$

The remaining fraction of GPP, not recovered in NPP, was defined as $\mathrm{C}$ residual:

C residual $=G P P-(A N P P+B N P P)$

Statistical analyses

The plant data were evaluated using the statistical software R (R Core Team 2019). Evaluation started with the definition of an appropriate statistical mixed model (Laird and Ware 1982; Verbeke and Molenberghs 2000). The yield data were assumed to be normally distributed and homoscedastic, while ANPP, BNPP and RFT data were assumed to be normally distributed and heteroscedastic due to the different intervals. These assumptions were based on a graphical residual analysis. The period was included as a fixed factor into the yield model. In the productivity and RFT model, the interval was treated as fixed factor and the effect of the different replicates on data variability was treated as a random factor. Using these models, analyses of variance were conducted to test for significant effects of the fixed factors on data variability. Furthermore, multiple contrast tests (Bretz et al. 2011) were performed in order to identify significant differences between the periods or intervals.

\section{Results}

Site characteristics

\section{Weather}

Compared to the long-term (1981-2010) mean annual temperature, the experimental years 2012 and 2013 showed no distinct differences, while 2014 was a comparably warm year (Table 2). In 2013, temperatures below average were observed in the beginning of the year, while from May 2013, no month of the remaining experimental period, with the exception of August 2014, had temperatures clearly below the long-term average with many substantially warmer months.

Regarding annual precipitation sums, the years 2012 and 2014 showed higher amounts than the long-term mean, while 2013 had less precipitation (Table 2). In 2012, the months May - August were all wetter than 1981-2010, while 2013 had a dry period in July and August. Also in 2014, a period with very low precipitation was recorded in summer but one month earlier than in 2013.

\section{Soil moisture and groundwater level}

The soil volumetric water content at the study site showed a typical annual pattern and ranged between $0.08 \pm 0.03 \mathrm{~m}^{3} \mathrm{~m}^{-3}$ at the last sampling day $(24 \mathrm{Ju}-$ ly 2014) and $0.43 \pm 0.05 \mathrm{~m}^{3} \mathrm{~m}^{-3}$ at 29 January 2013 (Fig. 1). Comparably low soil moisture was also observed in July and August 2013. The GWL, which ranged between -160 (27 September 2013) and$54 \mathrm{~cm}$ (5 February 2013), followed a similar annual course. However, there was a time-lag between the increase in soil moisture and GWL in autumn, while the drop of GWL in spring occurred earlier compared to that of soil moisture. 
Table 2 Mean monthly air temperature and precipitation during the period 2012-2014 compared to the long-term average (1981-2010)

\begin{tabular}{|c|c|c|c|c|c|c|c|c|c|c|c|c|c|}
\hline Period & Jan & Feb & Mar & Apr & May & Jun & Jul & Aug & Sep & Oct & Nov & Dec & Year \\
\hline \multicolumn{14}{|c|}{ Temperature $\left({ }^{\circ} \mathrm{C}\right)$} \\
\hline 2012 & 2.5 & -0.6 & 6.3 & 6.7 & 12.5 & 13.5 & 16.2 & 16.9 & 13.2 & 9.1 & 5.8 & 0.5 & 8.6 \\
\hline 2013 & 1.0 & 0.0 & -0.5 & 6.4 & 11.9 & 14.6 & 17.9 & 17.2 & 13.0 & 11.1 & 5.4 & 4.9 & 8.6 \\
\hline 2014 & 1.7 & 5.0 & 6.3 & 9.6 & 12.2 & 15.3 & 19.9 & 15.9 & 15.3 & 12.4 & 6.9 & 3.3 & 10.3 \\
\hline 1981-2010 & 1.1 & 1.3 & 3.6 & 7.3 & 11.6 & 14.7 & 17.2 & 16.7 & 13.3 & 9.4 & 4.8 & 2.1 & 8.6 \\
\hline \multicolumn{14}{|c|}{ Precipitation (mm) } \\
\hline 2012 & 107 & 24 & 11 & 44 & 57 & 92 & 122 & 94 & 77 & 65 & 56 & 98 & 846 \\
\hline 2013 & 79 & 28 & 9 & 20 & 89 & 106 & 52 & 54 & 82 & 83 & 59 & 79 & 739 \\
\hline 2014 & 68 & 43 & 30 & 74 & 88 & 38 & 51 & 123 & 73 & 65 & 23 & 193 & 867 \\
\hline 1981-2010 & 68 & 50 & 58 & 44 & 51 & 76 & 82 & 79 & 77 & 85 & 70 & 74 & 814 \\
\hline
\end{tabular}

Vegetation

\section{Above- and belowground productivity}

The dry matter (DM) yield significantly increased in the second year of the study period, while the differences in $\mathrm{C}$ and $\mathrm{N}$ yields were not significant (Table 3 ). A similar result was obtained regarding the different cutting and grazing events, which did not differ significantly between the two years in terms of $\mathrm{C}$ and $\mathrm{N}$ removals. The DM yields were higher at every cutting in the second year but this difference was only significant for the first cutting.

Measurements of total aboveground biomass (AGB) ranged between 1.8 and $5.0 \mathrm{Mg} \mathrm{DM} \mathrm{ha}{ }^{-1}$ on 2 April and 20 May 2014, respectively (Fig. 2a). AGB in October
2013 was on a high level, not significantly different compared to the AGB at the first two cuttings in 2014. In January 2014, mean AGB was distinctively lower but variability had strongly increased since October 2013, thus differences were not significant. Productivity of the first two growth periods in 2014 (I3 and I4) were similar, while it was significantly lower and almost halved during the third and fourth growth period (I5 and I6).

Between 29 October 2013 and 8 October 2014, cumulative BNPP was $2.9 \mathrm{Mg} \mathrm{DM} \mathrm{ha}{ }^{-1}$ (Fig. 2b). The significantly lowest BNPP of $0.1 \mathrm{Mg} \mathrm{DM} \mathrm{ha}{ }^{-1}$ was detected during the first ingrowth core interval until 15 January 2014. Root productivity was greatest during I3 (0.9 $\mathrm{Mg} \mathrm{DM} \mathrm{ha}{ }^{-1}$ ) and it significantly decreased during the second growth period until 4 July 2014 (I4). While the net root production between the second and third cut
Fig. 1 Volumetric soil water content (SWC) in samples from the $0-20 \mathrm{~cm}$ layer as well as groundwater levels (GWL) at the study site during the two-year study period. Error bars for SWC represent standard deviation $(n=$ 3)

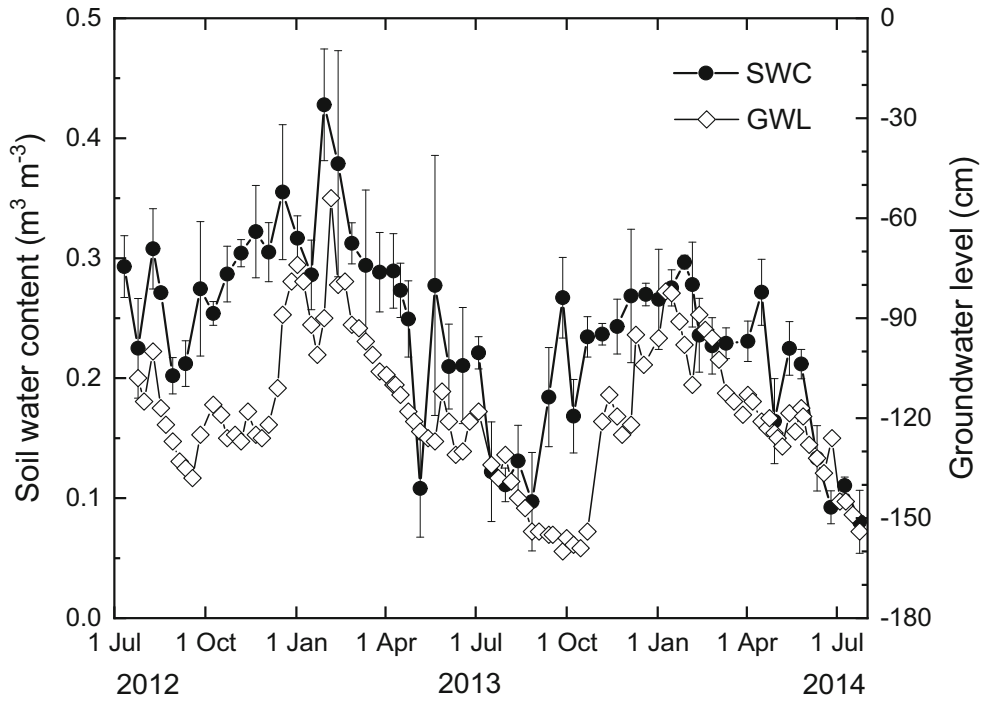


Table 3 Yields of dry matter (DM), carbon (C) and nitrogen (N) of the study site for single utilization events and in total for the two main study periods as well as the overall mean of both years. Different superscripted lowercase letters indicate significant differences between the two periods $(p<0.05)$. Values in brackets are standard errors $(n=3)$. $\mathrm{C}=$ cutting, $\mathrm{G}=$ grazing; subscripted numbers indicate the number of a cutting or grazing event in a calendar year

\begin{tabular}{|c|c|c|c|}
\hline Period & $\mathrm{DM}\left(\mathrm{Mg} \mathrm{ha}^{-1}\right)$ & $\mathrm{C}\left(\mathrm{Mg} \mathrm{ha}^{-1}\right)$ & $\mathrm{N}\left(\mathrm{kg} \mathrm{ha}^{-1}\right)$ \\
\hline \multicolumn{4}{|l|}{$2012 / 2013$} \\
\hline $\mathrm{C}_{3}: 2012-08-14$ & $2.2(0.1)^{\mathrm{a}}$ & $1.0(0.0)^{\mathrm{a}}$ & $68(2)^{\mathrm{a}}$ \\
\hline $\mathrm{G}_{1}: 2012-09-23-10-09$ & $1.9(0.3)^{\mathrm{a}}$ & $0.9(0.1)^{\mathrm{a}}$ & $62(8)^{\mathrm{a}}$ \\
\hline$C_{1}: 2013-05-31$ & $4.6(0.4)^{\mathrm{a}}$ & $2.1(0.2)^{\mathrm{a}}$ & $169(5)^{\mathrm{a}}$ \\
\hline $\mathrm{C}_{2}: 2013-07-14$ & $4.6(0.1)^{\mathrm{a}}$ & $2.1(0.0)^{\mathrm{a}}$ & $148(5)^{\mathrm{a}}$ \\
\hline Total & $13.3(0.5)^{\mathrm{a}}$ & $6.1(0.2)^{\mathrm{a}}$ & $446(10)^{\mathrm{a}}$ \\
\hline \multicolumn{4}{|l|}{ 2013/2014 } \\
\hline $\mathrm{C}_{3}: 2013-08-30$ & $3.4(0.6)^{\mathrm{a}}$ & $1.6(0.3)^{\mathrm{a}}$ & $104(16)^{\mathrm{a}}$ \\
\hline $\mathrm{G}_{1}: 2013-10-03-10-25$ & $1.3(0.2)^{\mathrm{a}}$ & $0.6(0.1)^{\mathrm{a}}$ & $51(9)^{\mathrm{a}}$ \\
\hline$C_{1}: 2014-05-16$ & $6.3(0.4)^{\mathrm{b}}$ & $2.8(0.2)^{\mathrm{a}}$ & $152(8)^{\mathrm{a}}$ \\
\hline $\mathrm{C}_{2}: 2014-06-25$ & $5.4(0.8)^{\mathrm{a}}$ & $2.4(0.4)^{\mathrm{a}}$ & $120(14)^{\mathrm{a}}$ \\
\hline Total & $16.3(0.9)^{b}$ & $7.4(0.4)^{\mathrm{a}}$ & $427(22)^{a}$ \\
\hline Mean & $14.8(0.7)$ & $6.8(0.3)$ & 437 (11) \\
\hline
\end{tabular}

increased again and was not significantly different compared to the primary growth, it significantly declined to a similar level as in $\mathrm{I} 2$ thereafter.

As AGB declined during the first two intervals over winter, ANPP was set 0 and consequently, $f_{B N P P}$ equaled 1 (Fig. 2b). After 2 April 2014, ANPP clearly exceeded BNPP and $\mathrm{f}_{\mathrm{BNPP}}$ therefore declined to 0.22 during the first growth period (I3). The fraction declined further to a value of 0.12 until the second cut (I4). However, during I5, $\mathrm{f}_{\mathrm{BNPP}}$ doubled (0.24) but strongly decreased after the third cut to a value of 0.09 (I6). The variability of $\mathrm{f}_{\mathrm{BNPP}}$ was generally high, particularly during the period 4 July -7 August 2014.

\section{Root functional traits}

The root length density (RLD) in 0-30 cm varied between $1.2 \mathrm{~cm} \mathrm{~cm}^{-3}$ for roots grown during I2 (15 January -2 April 2014) and $6.7 \mathrm{~cm} \mathrm{~cm}^{-3}$ during I3 (2 April -20 May 2014). During the non-growing season (I1 and I2) as well as the late growing season (I6), a significantly lower RLD compared to the main growing season was observed (Fig. 3a) while the RLD did not differ significantly between the first three growth periods in 2014 (I3 - I5).

Roots that grew during I1 had a rather small diameter, expressed as a significantly higher specific root length (SRL, $487 \mathrm{~m} \mathrm{~g}^{-1}$ ) compared to the other periods.
During I2, SRL significantly decreased to $104 \mathrm{~m} \mathrm{~g}^{-1}$. Subsequently, SRL significantly increased and remained on a rather constant level between 200 and $235 \mathrm{~m} \mathrm{~g}^{-1}$ during I3 - I5. At the end of the study period (I6), SRL decreased to a value of $150 \mathrm{~m} \mathrm{~g}^{-1}$ and in I5 and I6 the SRL was not significantly different compared to I2 before the onset of the growing season.

\section{Carbon exchange and allocation}

\section{Eddy covariance flux measurements}

The net ecosystem $\mathrm{CO}_{2}$ exchange (NEE) at the study site showed a typical annual course with mainly $\mathrm{CO}_{2}$ release from autumn until late winter and predominant $\mathrm{CO}_{2}$ uptake during the growing season (Fig. 4a). However, the $\mathrm{CO}_{2}$ uptake was interrupted by grassland cuttings, leading to net $\mathrm{CO}_{2}$ emissions during the subsequent days and a time lag until the $\mathrm{CO}_{2}$ sink activity was recovered. Maximum daily $\mathrm{CO}_{2}$ uptake was $-99.8 \mathrm{~kg}$ $\mathrm{CO}_{2}-\mathrm{C} \mathrm{ha}^{-1} \mathrm{~d}^{-1}$ on 12 July 2013 . The maximum daily $\mathrm{CO}_{2}$ release $\left(62.3 \mathrm{~kg} \mathrm{CO}_{2}-\mathrm{C} \mathrm{ha}^{-1} \mathrm{~d}^{-1}\right)$ was observed on 1 June 2013, one day after the first harvest of that year. During the two-year period 1 August 2012-31 July 2014, the daily sum of NEE was negative on 319 days and positive on 411 days.

Energy balance ratio (EBR) and availability of high quality data might indicate the quality and reliability of 


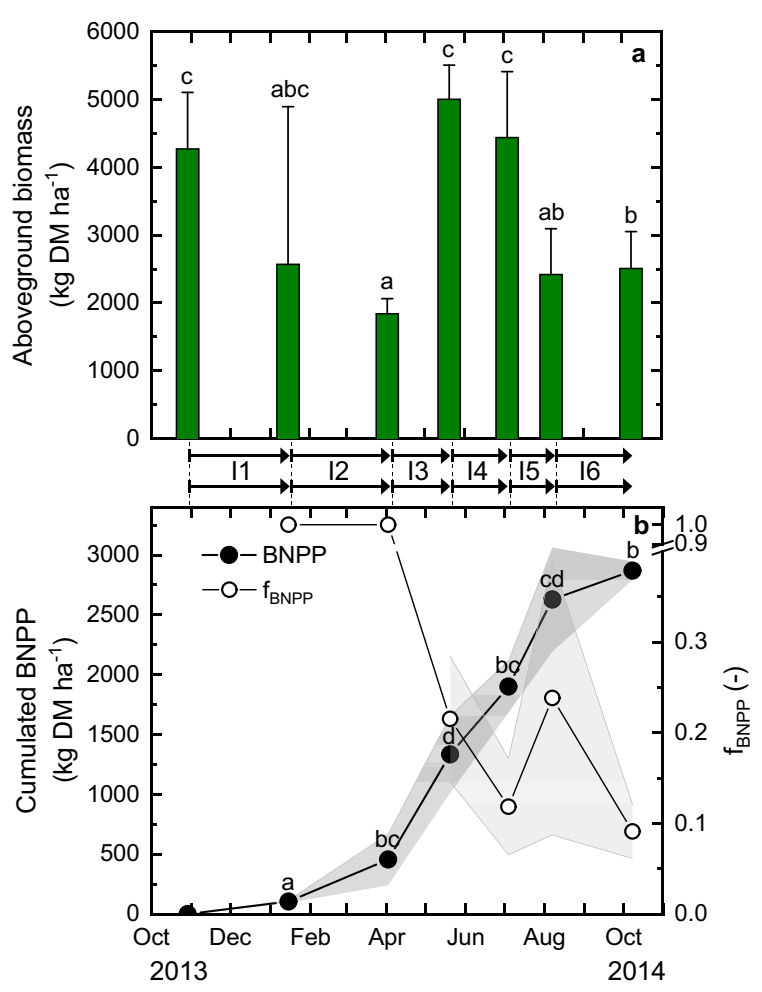

Fig. 2 Grassland productivity during the period October 2013 October 2014. (a): Temporal development of total aboveground biomass between sampling intervals (I). Note that the field was harvested after the samplings in May, July and August 2014. Error bars represent standard deviation $(n=9)$ and different lowercase letters indicate significant differences between the sampling dates with $p<0.05$. (b): Cumulative net primary production (BNPP) as measured by the ingrowth core method as well as the fraction of BNPP (fBNPP) on total net primary production for I1 - I6. Grey shaded areas represent standard deviation $(n=9)$ and different lowercase letters indicate significant differences between the $\mathrm{BNPP}$ of the respective intervals with $p<0.05$

measured $\mathrm{CO}_{2}$ fluxes at the $\mathrm{EC}$ station and associated seasonal budgets. Both parameters showed a distinct annual pattern with lower values in autumn or winter and highest values in spring (data availability) or summer (EBR) (Fig. 4c). During the two-year study period, mean daytime EBR was 0.65 and ranged between monthly means of 0.41 (January and February 2013) and 0.82 (July 2013). When the energy balance closure was analyzed as turbulent $(\mathrm{H}+\mathrm{LE})$ vs. available energy $\left(\mathrm{R}_{\mathrm{n}}-\mathrm{G}\right)$ for all available daytime measurements $(n=$ 8121 ), the slope of linear regression was 0.74 . The availability of NEE data after flux filtering averaged $63 \%$ for the two-year period and reached a minimum of $40 \%$ in December 2012 while it maximized with $80 \%$ in March 2013 and April 2014.
All grass growth periods of the years 2012-2014 that were fully covered by EC measurements were analyzed according to their mean diurnal courses of net $\mathrm{CO}_{2}$ exchange (Fig. 5). For the first growth, measurements beginning on 1 April were included in the analysis and the end of the fourth growth was set at 31 October. While the highest mean $\mathrm{CO}_{2}$ uptake rate was observed for the primary growth period in $2014\left(-3.6 \mathrm{~kg} \mathrm{CO}_{2}-\mathrm{C}\right.$ ha $^{-1} 30 \mathrm{~min}^{-1}$ at 12:30), generally higher nighttime $\mathrm{CO}_{2}$ release occurred during the second growth period compared to the first. Maximum mean $\mathrm{CO}_{2}$ release was $1.4 \mathrm{~kg} \mathrm{CO}_{2}-\mathrm{C} \mathrm{ha}{ }^{-1} 30 \mathrm{~min}^{-1}$ at 23:30 in the second growth phase of 2013. The daily amplitude was lowest in the fourth growth periods where peak $\mathrm{CO}_{2}$ uptake reached only $-1.37 \mathrm{~kg} \mathrm{CO}_{2}-\mathrm{C} \mathrm{ha}^{-1} 30 \mathrm{~min}^{-1}$ in 2013. Annual differences were most pronounced in the first growth periods with much lower daytime $\mathrm{CO}_{2}$ uptake rates in 2013 compared to 2014. This inter-annual variability was less for the other three growth periods.

\section{Carbon budgets}

Cumulative NEE and net biome productivity (NBP) differed due to management-related $\mathrm{C}$ inputs and removals, which overcompensated the $\mathrm{CO}_{2}-\mathrm{C}$ sink of the grassland after two years (Fig. 4b). In the first year (August 2012 - July 2013), cumulative NEE was $-1.56 \mathrm{Mg} \mathrm{CO}_{2}-\mathrm{C} \mathrm{ha}^{-1}$ while this net uptake increased to $-4.07 \mathrm{Mg} \mathrm{CO}_{2}-\mathrm{C} \mathrm{ha}^{-1}$ in the second year. In contrast, cumulative annual NBP was positive with $0.44 \mathrm{Mg} \mathrm{C}$ $\mathrm{ha}^{-1}$ in the first year and $0.13 \mathrm{Mg} \mathrm{C} \mathrm{ha}^{-1}$ in the second year. The $\mathrm{C}$ inputs from slurry application and cattle excretion were $4.1 \mathrm{Mg} \mathrm{C} \mathrm{ha}^{-1}$ in the first year and 3.3 $\mathrm{Mg} \mathrm{C} \mathrm{ha}{ }^{-1}$ in the second year.

Partitioned gross primary production (GPP) and ecosystem respiration $\left(\mathrm{R}_{\mathrm{ECO}}\right)$ reached maximum monthly budgets of $-3.13 \mathrm{Mg} \mathrm{CO}_{2}-\mathrm{C} \mathrm{ha}^{-1}$ in June 2014 and $1.97 \mathrm{Mg} \mathrm{CO}_{2}-\mathrm{C} \mathrm{ha}^{-1}$ in July 2013, respectively. GPP dominated over $\mathrm{R}_{\mathrm{ECO}}$ during the growing season but $\mathrm{R}_{\mathrm{ECO}}$ started to overcompensate GPP from October in both years, which became apparent in positive monthly budgets of NEE (Fig. 6). In 2013, NEE turned negative in April again while in 2014, this was already the case in March. The month with highest cumulative net $\mathrm{CO}_{2}$ uptake was June $2014\left(-1.47 \mathrm{Mg} \mathrm{CO}_{2}-\mathrm{C} \mathrm{ha}^{-1}\right)$ and highest cumulative net $\mathrm{CO}_{2}$ release occurred in November $2012\left(0.58 \mathrm{Mg} \mathrm{CO}_{2}-\mathrm{C} \mathrm{ha}^{-1}\right)$. Greatest differences between NEE and NBP occurred in those months where only slurry application or only biomass removals took 
Fig. 3 Temporal development of the root functional traits root length density (a) and specific root length (b) during the intervals (I) 1-6 from October 2013 - October 2014. Extracted roots have been grown into ingrowth cores since the previous sampling. Grey shaded areas represent standard deviation $(n=9)$ and different lowercase letters indicate significant differences of respective root traits between the different intervals with $p<0.05$

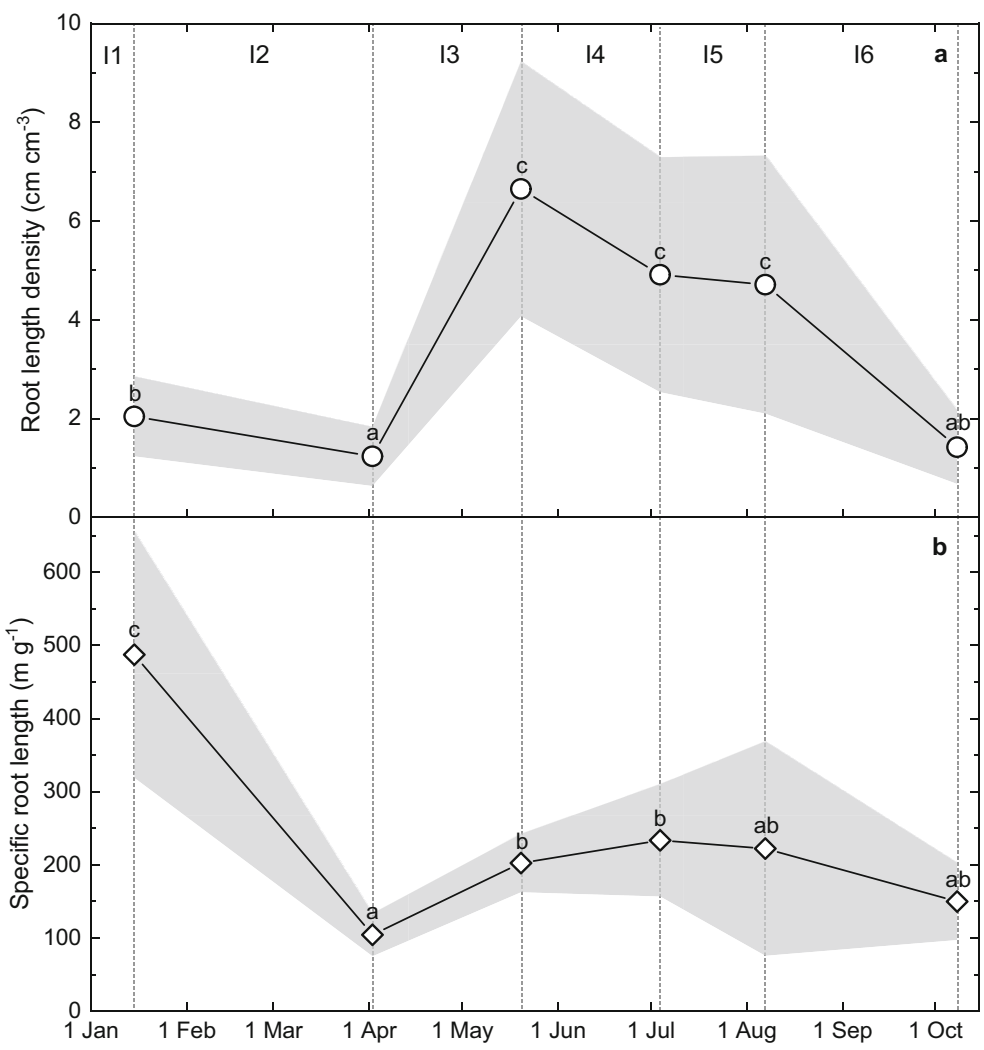

place. Thus, slurry application in autumn (November) or spring (March) decreased NBP compared to NEE, while grassland cuttings in May strongly increased NBP.

\section{Allocation of assimilated carbon}

Highest productivity (NPP) was observed during intervals with highest GPP (Fig. 7a). However, the partitioning between ANPP and BNPP was substantially different between the intervals. While assimilated $\mathrm{C}$ was solely allocated to roots during I1 and I2 with low $\mathrm{CO}_{2}$ fixation (i.e., $\mathrm{BNPP}=\mathrm{NPP}$ ), $\mathrm{BNPP}$ remained at a comparably low level during the growing season (I3 I5), whereas ANPP largely increased. The CUE was low $(<0.2)$ during the non-growing season, resulting in a large fraction of the $\mathrm{C}$ residual. During the primary growth phase (I3), the CUE substantially increased to 0.81 and decreased progressively during the two subsequent regrowth periods to values of 0.71 (I4) and 0.62 (I5). $\mathrm{R}_{\mathrm{ECO}}$ did not follow the same pattern as GPP since it decreased from I1 to I2 and maximized later (I4) than GPP (I3).
In a multiple regression analysis, CUE was related to cumulative GPP and mean soil moisture at the $5 \mathrm{~cm}$ depth during the five analyzed intervals (Fig. 7b). While CUE increased linearly with increasing GPP, the relationship of CUE vs. soil moisture followed an optimum function. CUE was low in the non-growing season at high soil moisture around $0.2 \mathrm{~m}^{3} \mathrm{~m}^{-3}$, whereas it was substantially higher at lower soil moisture during the growing season. However, CUE decreased successively with further decreasing soil moisture from I3 $\left(0.18 \mathrm{~m}^{3} \mathrm{~m}^{-3}\right)$ over I4 $\left(0.12 \mathrm{~m}^{3} \mathrm{~m}^{-3}\right)$ to I5 $\left(0.07 \mathrm{~m}^{3} \mathrm{~m}^{-3}\right)$.

\section{Discussion}

Resource availability determines carbon use efficiency

As pronounced in $\mathrm{H} 1$, the study site was characterized by a high CUE for the conversion of photoassimilates to plant biomass. On average, we observed a CUE of 0.71 during the 2014 growing season with a maximum value 


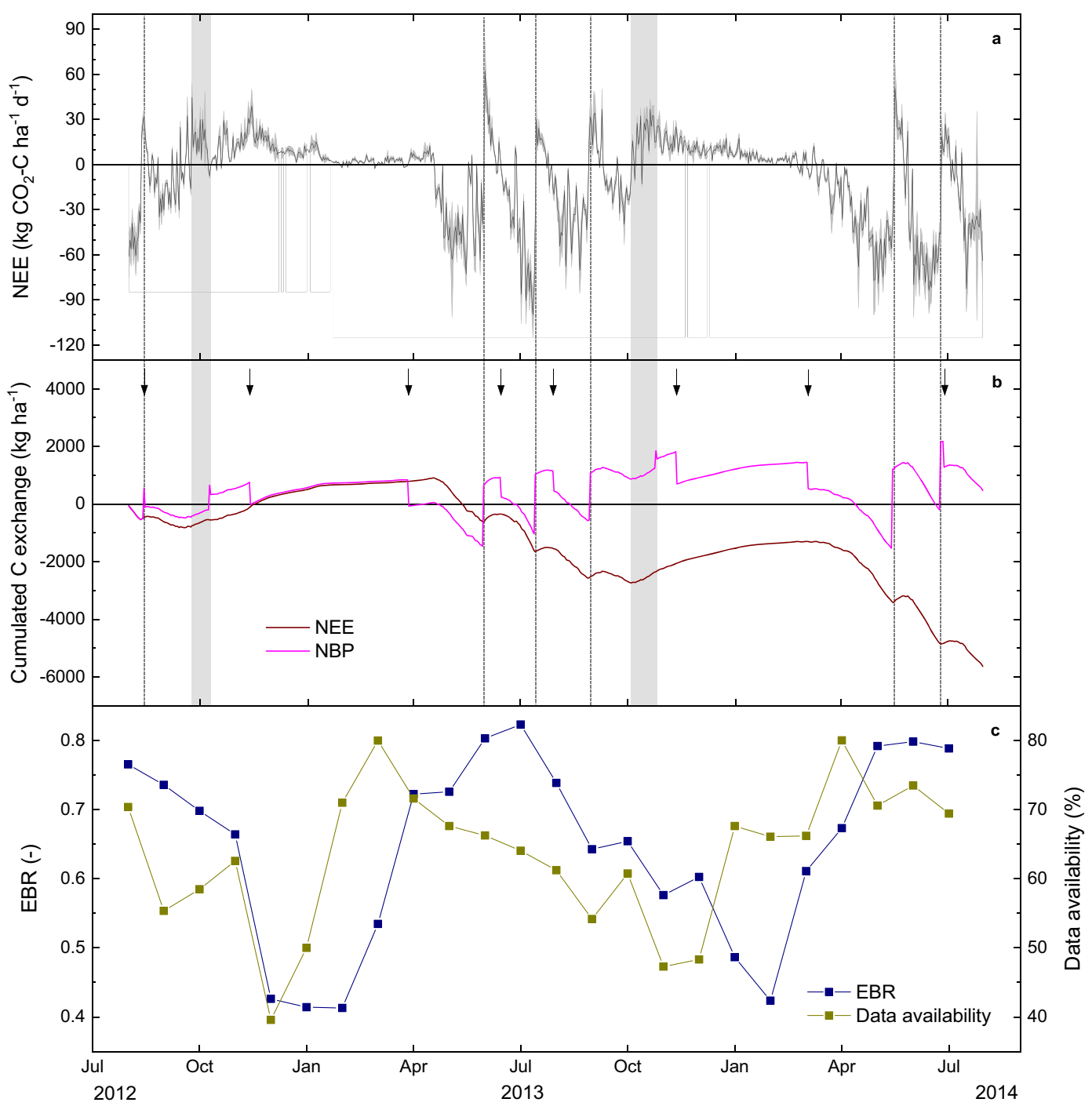

Fig. 4 (a): Daily sums of gap-filled net ecosystem exchange (NEE) of $\mathrm{CO}_{2}$ measured at the eddy covariance station during the period 1 August 2012-31 July 2014. The uncertainty range represents daily averages of measurement uncertainty as the sum of random error and instrumental noise. (b): Cumulative NEE and net biome productivity (NBP) for the same period. Grey dotted

of 0.81 for the primary growth. In a semiarid environment, Saliendra et al. (2018) obtained a CUE of only 0.26 for a grassland, while the CUE reached 0.43 for an alfalfa field. The authors explained the higher efficiency of alfalfa by its ability to access water from deeper soil layers, unavailable for shallow rooting grasses. This comparison underlines the favorable conditions of humid temperate climates for efficient forage production from grasslands on the one hand and the strong effect of belowground resource availability on the CUE of lines and grey shaded areas in (a) and (b) represent grassland cuttings and grazing periods, respectively. Arrows in (b) represent slurry applications. (c): Monthly averages of daytime energy balance ratio (EBR) and proportion of available high quality data after flux filtering. EBR was calculated for all time steps with available high quality data and $\mathrm{Rn}-\mathrm{G} \geq 20 \mathrm{~W} \mathrm{~m}^{-2}$

photoassimilates on the other hand. Corresponding to the CUE presented here, several partitioning studies have been conducted on grasses or grasslands, most of which using pulse labeling with ${ }^{13} \mathrm{C}$ or ${ }^{14} \mathrm{C}$ over rather short periods of a few days or weeks. In an overview presented by Riederer et al. (2015), the fraction of recovered $\mathrm{C}$ in grassland biomass ranged between 0.32 and 0.88 with a mean value of 0.61 . Despite different methodological approaches, the observed CUE of this study fits well into this range and confirmed the 


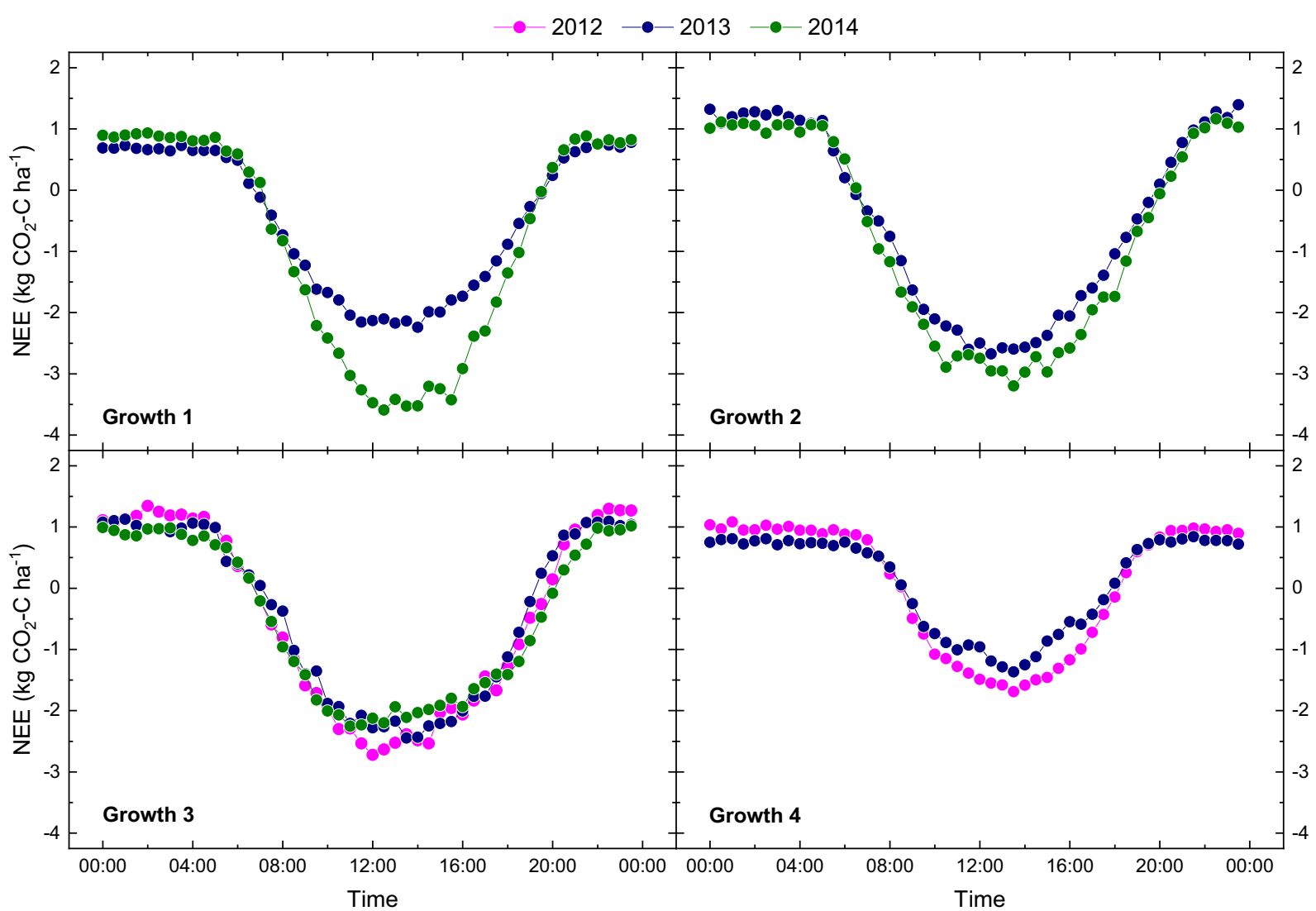

Fig. 5 Mean diurnal courses of net ecosystem exchange (NEE) during different growth periods at the studied grassland site. The beginning of the first growth period was set on 1 April and the end

expected high efficiency at this intensively managed grassland site.

Since GPP and CUE were positively correlated (Fig. $7 \mathrm{a}$ and $\mathrm{b}$ ), $\mathrm{C}$ was more effectively used for biomass production during periods of highest photosynthetic activity. Under unfavorable growth conditions, such as during the non-growing season (I1, I2) or at very low soil moisture (I5), not only GPP was reduced but also the efficiency in converting the fixed $\mathrm{C}$ to plant biomass. The $\mathrm{C}$ residual not recovered in biomass can be either lost via autotrophic respiration $\left(\mathrm{R}_{\mathrm{a}}\right)$ from shoots, roots and microbial respiration of root exudates or via root exudates incorporated in microbial biomass and SOM (net rhizodeposition) or leached from the soil profile as dissolved organic $\mathrm{C}$. Since only $\mathrm{R}_{\mathrm{ECO}}$ can be estimated using the EC approach, $\mathrm{R}_{\mathrm{a}}$ cannot be quantified. The increase in cumulative $\mathrm{R}_{\mathrm{ECO}}$ between I3 and I4 (Fig. 7a) can be attributed to increasing temperature. Although the temperature further increased, $\mathrm{R}_{\mathrm{ECO}}$ decreased during I5. It seems most likely that soil microbial activity of the fourth growth period was set on 31 October. The growth periods 2-4 started on the first day after grassland defoliation

was limited by the low soil moisture during this period and a reduction in heterotrophic respiration $\left(\mathrm{R}_{\mathrm{h}}\right)$ was responsible for the lower $\mathrm{R}_{\mathrm{ECO}}$. This was underlined by the constant $\mathrm{C}$ residual between $\mathrm{I} 4$ and $\mathrm{I}$, indicating that $R_{a}$ did not substantially change while NPP decreased and thus CUE.

Under conditions of heat and drought stress, plants use their stomata to regulate transpiration and prevent high water losses (Manzoni et al. 2013), which, as a tradeoff, reduces the intensity of $\mathrm{CO}_{2}$ uptake. Consequently, productivity decreases while $\mathrm{CO}_{2}$ losses via nighttime respiration might not necessarily be reduced as an effect of higher temperatures. This can be partly perceived from the mean diurnal courses of net ecosystem $\mathrm{CO}_{2}$ exchange (NEE) since nighttime NEE was generally higher during the summer regrowth periods compared to the primary growth when temperatures were lower (Fig. 5). In 2013, for example, nighttime NEE increased from 0.65 (growth 1) to 1.2 (growth 2) and $1.0 \mathrm{~kg} \mathrm{CO}_{2}-\mathrm{C} \mathrm{ha}^{-1} 30 \mathrm{~min}^{-1}$ (growth 3), while mean 
Fig. 6 Monthly budgets of ecosystem respiration $\left(\mathrm{R}_{\mathrm{ECO}}\right)$, gross primary production (GPP), net ecosystem exchange (NEE) and net biome productivity (NBP) as well as $\mathrm{C}$ inputs via slurry application or excretion of grazing cattle and $\mathrm{C}$ removals via harvest during the two-year study period. $\mathrm{R}_{\mathrm{ECO}}$ and GPP were partitioned from eddy covariance measurements of NEE. NBP was calculated as the sum of NEE, $\mathrm{C}$ inputs and $\mathrm{C}$ removals

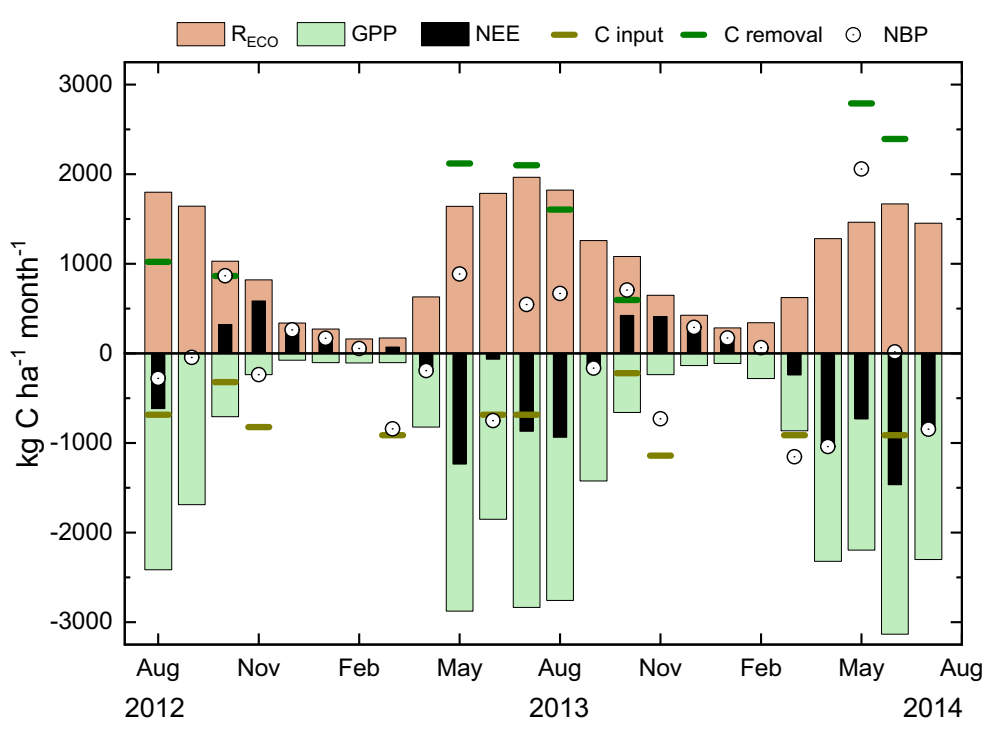

daytime NEE remained on a similar level (roughly $-1.3 \mathrm{~kg} \mathrm{CO}_{2}-\mathrm{C} \mathrm{ha}{ }^{-1} 30 \mathrm{~min}^{-1}$ ). However, the specific responses of $R_{a}$ and $R_{h}$ to altered environmental conditions remain uncertain.

Large uncertainties also exist concerning site-specific quantification of rhizodeposition. During periods with high $\mathrm{f}_{\mathrm{BNPP}}, \mathrm{C}$ translocation to the soil via rhizodeposition is potentially increased, thus lowering plant CUE. At the study site, significant photosynthetic activity was observed during the non-growing season and roughly $1690 \mathrm{~kg} \mathrm{CO}_{2}-\mathrm{C}^{-1}$ were assimilated by

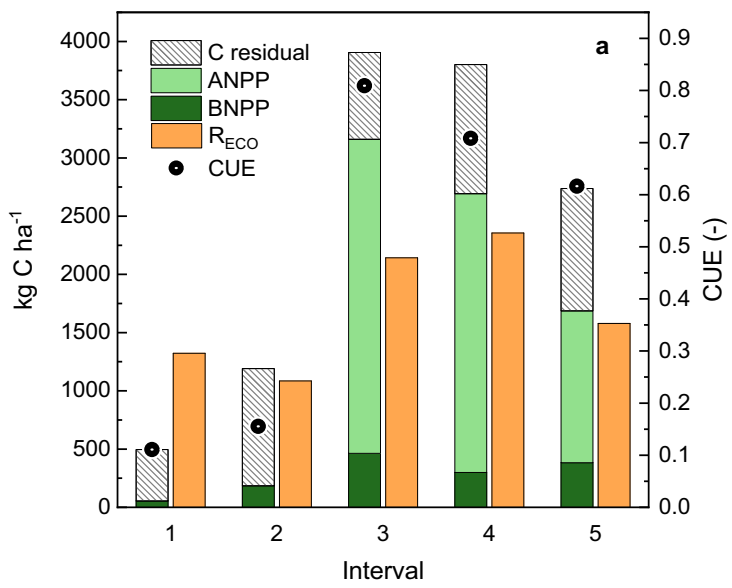

Fig. 7 (a): Cumulative gross primary production (GPP) and ecosystem respiration $\left(\mathrm{R}_{\mathrm{ECO}}\right)$ partitioned from eddy covariance $(\mathrm{EC})$ measurements of net ecosystem $\mathrm{CO}_{2}$ exchange for intervals $1-5$ of the period 29 October 2013-7 August 2014 as defined in Fig. 2. GPP was further partitioned into aboveground (ANPP) and belowground net primary production (BNPP) as well as a carbon (C) residual defined as the difference between GPP and net primary the grassland between October and April although no net shoot growth was observed (Fig. 7a). Consequently, all assimilates were respired or allocated belowground with a very low plant CUE of $0.11-0.16$. During I1, $\mathrm{R}_{\mathrm{ECO}}$ was much larger compared to the $\mathrm{C}$ residual, indicating a high fraction of $\mathrm{R}_{\mathrm{h}}$ on total $\mathrm{R}_{\mathrm{ECO}}$. In a conservative approach, the minimum amount of net rhizodeposition during $\mathrm{I} 2$ can be calculated when it is assumed that the $\mathrm{C}$ residual $=\mathrm{R}_{\mathrm{a}}$ in $\mathrm{I} 1$ and the subsequent decrease in $R_{E C O}$ is fully attributed to $R_{h}$. In this case, net rhizodeposition would be $565 \mathrm{~kg} \mathrm{C}^{-1}$,

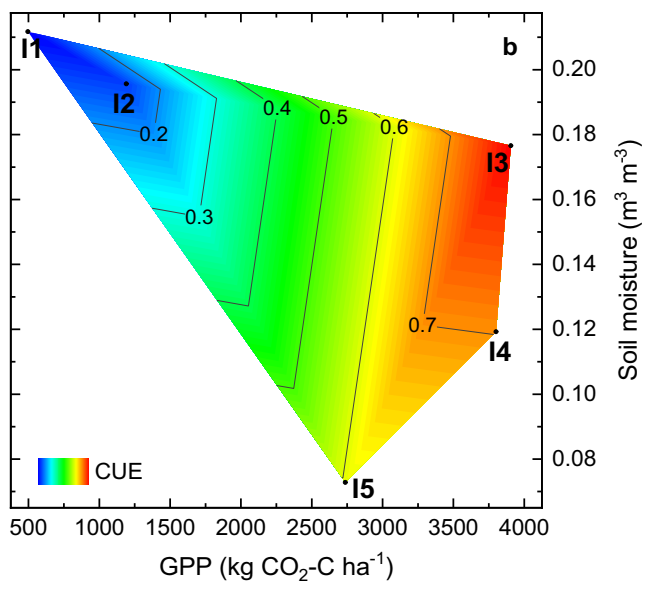

production $(\mathrm{NPP})$ where NPP $=$ ANPP + BNPP. The carbon use efficiency (CUE) was calculated as the fraction of NPP on total GPP. (b): Multiple regression analysis of CUE vs. cumulative GPP and mean soil moisture at the $5 \mathrm{~cm}$ depth measured at the EC station during the specific intervals. I1 - I5 relates to the five intervals from panel a 
corresponding to three-times the BNPP and $47 \%$ of GPP. It can be concluded that despite comparably high photosynthetic activity during the non-growing season (Fig. 2), most of the assimilated $\mathrm{C}$ was immediately deposited to the soil or respired by the plants.

Pausch and Kuzyakov (2018) suggested that the ratios between gross and net rhizodeposition and $\mathrm{C}$ allocated to roots are rather constant among plant species (crops or grasslands) despite different $\mathrm{C}$ allocation patterns and are generally around 0.7 and 0.5 , respectively. Using these ratios results in an estimated amount of $2 \mathrm{Mg} \mathrm{C} \mathrm{ha}{ }^{-1}$ deposited to the soil during one year of BNPP measurement (Fig. 2) and roughly $1.5 \mathrm{Mg} \mathrm{C} \mathrm{ha}^{-1}$ of these deposits remaining in the soil as microbial biomass or SOM. For the non-growing season, the ratio of 0.5 results in low estimates of net rhizodeposition accounting for only 6 (I1) and 9\% (I2) of the C residual. This approach suggests that most of the assimilated $\mathrm{C}$ was lost via $R_{a}$. Using the ratio of 0.5 , net rhizodeposition reached $232 \mathrm{~kg} \mathrm{C}$ ha ${ }^{-1}$ during the primary growth, which accounted for $31 \%$ of the $\mathrm{C}$ residual. This fraction was lower during the first $(13 \%)$ and second regrowth period (18\%). However, the exact quantification of rhizodeposition remains challenging and its temporal dynamics over the course of the year are rarely studied. Accordingly, Remus and Augustin (2016) demonstrated for a rye crop that $\mathrm{C}$ partitioning coefficients are highly dynamic and depend on absolute shoot growth and the phenological stage of the plant, challenging their generalization.

\section{Shoot-dominated carbon allocation}

In line with the functional equilibrium theory (Brouwer 1963), the very high nutrient availability is the most likely reason for low root growth at the study site as belowground resources can be easily accessed without substantial investment in a dense rooting system. For a grassland ecosystem in Inner Mongolia, Li et al. (2011) showed that the addition of the currently limiting belowground resource (water or $\mathrm{N}$ ) reduces $\mathrm{f}_{\mathrm{BNPP}}$, while strongly increasing ANPP. The observations from a temperate grassland in this study fit well into this pattern, and thus confirm our $\mathrm{H} 2$, as the high $\mathrm{N}$ fertilization rates and the soil $\mathrm{P}_{2} \mathrm{O}_{5}$ concentration (Table 1), which characterized the site as phosphor $(\mathrm{P})$-oversupplied according to the German $\mathrm{P}$ classification system (VDLUFA 2018), were associated with high dry matter and $\mathrm{N}$ yields (Table 3 ) but low BNPP.
In contrast to high harvest yields and ANPP, the $\mathrm{f}_{\mathrm{BNPP}}$ was considerably low during the growing season 2014, particularly when compared to observed $f_{\text {BNPP }}$ of permanent grassland sites under semi-intensive management with low external $\mathrm{N}$ supply in northern Germany (Loges et al. 2018). On average of unfertilized and fertilized treatments, Loges et al. (2018) measured net primary production (NPP) of $13.3 \mathrm{Mg}$ organic matter (OM) ha ${ }^{-1}$ with an $\mathrm{f}_{\mathrm{BNPP}}$ of 0.32 . NPP of the grassland under study was $17.2 \mathrm{Mg} \mathrm{OM} \mathrm{ha}^{-1}$ while the $\mathrm{f}_{\mathrm{BNPP}}$ was only 0.17 . In their review on $\mathrm{C}$ allocation patterns, Pausch and Kuzyakov (2018) obtained mean values of 0.45 and 0.34 for $\mathrm{C}$ allocation to shoot biomass in annual crops and grasslands, respectively. These values originated from several short-term ${ }^{13} \mathrm{C}$ or ${ }^{14} \mathrm{C}$ labeling studies. Our multi-method approach resulted in a value of 0.53 for aboveground $\mathrm{C}$ allocation during 29 October 2013-7 August 2014 (I1 - I5). The retention of C in shoots maximized with 0.69 during the primary growth period. Thus, the study site was characterized by an atypically strong retention of assimilated $\mathrm{C}$ in shoots, although care has to be taken due to the comparability of the different methodological approaches.

The rather low root length density (RLD) at the study site, which reached a maximum of $6.7 \mathrm{~cm} \mathrm{~cm}^{-3}$ during the primary growth in 2014, corresponds to the low belowground $\mathrm{C}$ allocation. This value was comparable to maximum RLD found in a pot experiment with different grass species by Ravenek et al. (2016). In contrast, Chen et al. (2016) measured maximum RLD of $18 \mathrm{~cm} \mathrm{~cm}^{-3}$ in semi-intensive managed permanent grassland swards in northern Germany. However, they found a significant effect of sward age on RLD, which decreased to a mean value of roughly $10 \mathrm{~cm} \mathrm{~cm}^{-3}$ under 5 year-old swards when pooled over the four growth periods compared to $17 \mathrm{~cm} \mathrm{~cm}^{-3}$ under 1-year old swards. At the old permanent grassland of this study, mean RLD over the four growth periods was only $4.4 \mathrm{~cm} \mathrm{~cm}^{-3}$.

These strong discrepancies between two differently managed permanent grassland systems under similar climatic conditions emphasize the importance of soil nutrient availability on $\mathrm{C}$ allocation and root growth in grasslands. Lorenz and Rogler (1967) already reported decreasing root:shoot ratios under elevated $\mathrm{N}$ fertilization levels several decades ago. Under conditions of limited $\mathrm{N}$ availability (Chen et al. 2016), significantly thinner roots were observed during the regrowth periods compared to the primary growth (SRL up to $450 \mathrm{~m} \mathrm{~g}^{-1}$ ), 
compensating for reduced BNPP and maintaining a high rooting density in the soil. In this study, this pattern was only observed during the first half of the winter, possibly as a reaction on reduced $\mathrm{N}$ availability due to leaching losses. Potential N leaching was illustrated by a strongly increasing groundwater level (GWL) between October 2013 and January 2014 and the time shift between increased soil moisture and GWL rise indicated the downward movement of water through the soil (Fig. 1).

Due to the sandy texture of the study site, field capacity was estimated with only $0.13 \mathrm{~m}^{3} \mathrm{~m}^{-3}$ while total porosity was $0.42 \mathrm{~m}^{3} \mathrm{~m}^{-3}$ (Schaap et al. 2001), indicating a large fraction of coarse and fast draining soil pores. This low water holding capacity makes the site susceptible to drought and soil water availability the more relevant resource for limiting grass growth compared to nutrient availability under the current management. During I4 in July 2014, ANPP was significantly reduced at very low soil moisture, confirming results by Li et al. (2011) who demonstrated that nitrogen use efficiency (NUE) decreases when water is the main limiting factor for grass growth. In this period, $\mathrm{C}$ allocation to roots was stimulated as indicated by the increased $f_{B N P P}$ (Fig. 2). Since grassland $N$ uptake was limited by low water availability, high amounts of residual $\mathrm{N}$ might have been available after the third cut. The high precipitation in August 2014 suddenly increased the availability of this residual soil $\mathrm{N}$, which explains the very low $\mathrm{f}_{\mathrm{BNPP}}$ and the strong decline of RLD during I6.

\section{Carbon losses from intensive permanent grassland}

The study site acted as a net sink for $\mathrm{CO}_{2}$ when measured and gap-filled $\mathrm{CO}_{2}$ fluxes were cumulated for the two-year study period. However, the study site was a net source for $\mathrm{C}$ when management related $\mathrm{C}$ fluxes (organic fertilization, harvest) were considered (Fig. 4b). This result confirmed our $\mathrm{H} 3$ since it documented that the site was not in a phase of increasing SOC stocks, thus equilibrium had already been reached. Compared to results from a Europe-wide study across 19 European grasslands (Gilmanov et al. 2007), our site can be classified as a strong $\mathrm{CO}_{2}$ sink as its mean annual net $\mathrm{CO}_{2}$ uptake of $-2.82 \mathrm{Mg} \mathrm{CO}_{2}-\mathrm{C} \mathrm{ha}^{-1} \mathrm{yr}^{-1}$ was slightly stronger than the $75 \%$ percentile $\left(-2.62 \mathrm{Mg} \mathrm{CO}_{2}-\mathrm{C}\right.$ $\mathrm{ha}^{-1} \mathrm{yr}^{-1}$ ) observed by Gilmanov et al. (2007). However, most of the study sites were managed with low intensity, thus, they were not representative for grasslands of highly intensive dairy systems in northwest Europe. At a low-intensity mountain grassland in the Austrian Alps for example, Wohlfahrt et al. (2008) documented a near-neutral NEE over six years of EC measurements, while Peichl et al. (2011) observed a similar net $\mathrm{CO}_{2}$ uptake $\left(-2.77 \mathrm{Mg} \mathrm{CO}_{2}-\mathrm{C} \mathrm{ha}^{-1} \mathrm{yr}^{-1}\right)$ at an intensively managed grassland in Ireland compared to this study. The comparably high $\mathrm{CO}_{2}$ sink of our study site therefore reflects its high productivity and points to the fact that $\mathrm{R}_{\mathrm{ECO}}$ does not increase proportionally with GPP across different sites as also shown by a slope of 0.76 in the study of Gilmanov et al. (2007). With the combined measurements conducted in this study, these observations were clearly confirmed by the higher CUE at increasing GPP (Fig. 7).

Net $\mathrm{C}$ losses due to high biomass removals from intensively utilized fields have mainly been reported for croplands (Kutsch et al. 2010; Poyda et al. 2019; Schmidt et al. 2012) but also for grasslands (Skinner 2008, 2013; Soussana et al. 2010) in studies based on the same methodological approach. The observed net $\mathrm{C}$ loss of $0.29 \mathrm{Mg} \mathrm{C} \mathrm{ha}^{-1} \mathrm{yr}^{-1}$ on average over the two study years was lower than that reported by Skinner (2008), which averaged $1.13 \mathrm{Mg} \mathrm{C} \mathrm{ha}^{-1} \mathrm{yr}^{-1}$ for a grass-based pasture in Pennsylvania. Consistently, Skinner (2013) observed substantial C losses from two pastures with high and low $\mathrm{N}$ fertilization that increased with $\mathrm{N}$ addition and averaged 1.22 (High-N-pasture) and $1.02 \mathrm{Mg} \mathrm{C}^{-1} \mathrm{yr}^{-1}$ (Low-N-pasture). Both results were explained by a possibly saturated $\mathrm{C}$ sequestration potential due to grassland age ( $>35 \mathrm{yr}$ ) and $\mathrm{C}$ removals with harvested biomass larger than the annual net $\mathrm{CO}_{2^{-}}$ C uptake.

Contrasting results from different grassland systems underline that no universal relationship between management intensity (i.e., $\mathrm{N}$ fertilization) and the $\mathrm{C}$ budget of a grassland site exists. This relationship strongly depends on grassland age and preliminary management and results might point to contrasting conclusions depending on these factors. Thus, linking recent trends in SOC stocks to recent management practices without careful consideration of past land use and management might lead to misinterpretations (Powlson et al. 2010). For example, Kim and Henry (2013) observed no effect on NEE but a $100 \%$ increase of aboveground plant biomass by the addition of $60 \mathrm{~kg} \mathrm{~N} \mathrm{ha}^{-1} \mathrm{yr}^{-1}$ on a long-term ( $25 \mathrm{yr})$ unfertilized grassland in Canada. In contrast, an intensively managed grassland in 
Switzerland (230 $\mathrm{kg} \mathrm{N} \mathrm{ha}^{-1} \mathrm{yr}^{-1}, 4-5$ cuts yr $^{-1}$ ) acted as a net $\mathrm{C}$ sink, while an extensively managed field without fertilization was a net $C$ source (Ammann et al. 2009). While the grassland studied by Kim and Henry (2013) was adopted to $\mathrm{N}$ limitation and likely reacted to enhanced $\mathrm{N}$ availability with a strongly reduced $\mathrm{f}_{\mathrm{BNPP}}$, the Swiss site was previously converted from arable cropping. To realize the large $\mathrm{C}$ sequestration potential after grassland establishment, fertilization is needed to ensure a certain level of productivity and therefore $\mathrm{C}$ inputs to build up SOC stocks (Ammann et al. 2009; Loges et al. 2018). The management intensity that optimizes $\mathrm{C}$ sequestration, therefore, is highly site-specific.

Our results underline that permanent grasslands do not sequester $\mathrm{C}$ per se and suggest that a reduced fertilization intensity will be beneficial for $\mathrm{C}$ sequestration on intensively managed grasslands confirming the conclusion of Jones and Donelly (2004). The soil properties of our study site might classify it as "black sand" according to Vos et al. (2018). For arable sandy and C-rich top soils, Springob and Kirchmann (2002) proved that a major fraction of the SOM is present as particulate and refractory compounds and is not in process of net decomposition. The high $\mathrm{C}$ stock of the study site might therefore reflect historical land use and vegetation rather than management during the previous few decades. In addition to the already low $\mathrm{C}$ sequestration potential at the study site, our results clearly documented that only a minor fraction of the assimilated $\mathrm{C}$ was allocated belowground, most likely as an adaptation mechanism to very high soil nutrient availability. As high amounts of fertilizers are available on this dairy farm in the form of slurry, a strong reduction of mineral $\mathrm{N}$ fertilization seems reasonable and could stimulate root production and therefore increase the residence time of $\mathrm{C}$ in the system. This measure might already be sufficient to compensate for the comparably small recent $\mathrm{C}$ source of the site.

\section{Conclusions}

Permanent grasslands are able to convert photosynthetically assimilated $\mathrm{C}$ to plant biomass with a high efficiency, generating high absolute $\mathrm{C}$ inputs to the plantsoil system. However, the natural mechanism of perennial grasses to allocate large fractions of assimilated $\mathrm{C}$ to root biomass can be impeded by adaptation mechanisms to high nutrient availability, decreasing the amounts of
$\mathrm{C}$ remaining in the system. While the $\mathrm{C}$ sequestration potential of grasslands is affected by site conditions, grassland age and historical land use, the recent management determines to which degree this potential is realized. Due to its sandy texture and high $\mathrm{C}$ content as well as the long-term utilization as permanent grassland, the recent $C$ sequestration potential of the study site is low. Management measures should therefore focus on preventing $\mathrm{C}$ losses, which is also fundamental to maintain a high soil fertility. A strong reduction of mineral $\mathrm{N}$ fertilization is likely to promote the natural ability of the grassland for belowground resource acquisition by investing in dense rooting systems and thereby increasing soil $\mathrm{C}$ inputs. This would also promote the grassland's resilience to unfavorable conditions and reduce the need for grassland renovation threatening its $\mathrm{C}$ stocks.

Acknowledgements This study was funded by the former Innovationsstiftung Schleswig-Holstein (ISH) and the Ministry of Energy, Agriculture, the Environment and Rural Areas (MELUR) of Schleswig-Holstein. Their financial support is gratefully acknowledged. We thank the farmer of the study site for his cooperation and the permission to conduct our measurements at his site. Furthermore, the revisions of two anonymous referees helped to substantially improve the quality of this article, which we appreciate explicitly.

Funding Open Access funding enabled and organized by Projekt DEAL.

Data availability The data from this study will be made available by the authors upon request.

Open Access This article is licensed under a Creative Commons Attribution 4.0 International License, which permits use, sharing, adaptation, distribution and reproduction in any medium or format, as long as you give appropriate credit to the original author(s) and the source, provide a link to the Creative Commons licence, and indicate if changes were made. The images or other third party material in this article are included in the article's Creative Commons licence, unless indicated otherwise in a credit line to the material. If material is not included in the article's Creative Commons licence and your intended use is not permitted by statutory regulation or exceeds the permitted use, you will need to obtain permission directly from the copyright holder. To view a copy of this licence, visit http://creativecommons.org/licenses/by/4.0/.

\section{References}

Ammann C, Spirig C, Leifeld J, Neftel A (2009) Assessment of the nitrogen and carbon budget of two managed temperate grassland fields. Agric Ecosyst Environ 133:150-162. https://doi.org/10.1016/j.agee.2009.05.006 
Baldocchi DD, Hicks BB, Meyers TP (1988) Measuring biosphere-atmosphere exchanges of biologically related gases with micrometeorological methods. Ecology 69:13311340. https://doi.org/10.2307/1941631

Baldocchi DD, Falge E, Gu L, Olson R, Hollinger D, Running S, Anthoni P, Bernhofer C, Davis K, Fuentes J, Goldstein A, Katul G, Law B, Lee X, Malhi Y, Meyers T, Munger JW, Oechel W, Pilegaard K, Schmid HP, Valentini R, Verma S, Vesala T, Wilson K, Wofsy S (2001) FLUXNET: a new tool to study the temporal and spatial variability of ecosystemscale carbon dioxide, water vapor and energy flux densities. B Am Meteorol Soc 82:2415-2434. https://doi.org/10.1175 /1520-0477(2001)082<2415:FANTTS >2.3.CO;2

Blume H-P, Brümmer G (1986) Agriculture, landscapes and soils of Schleswig-Holstein. Mitt Dtsch Bodenkdl Ges 51:3-14

Bretz F, Hothorn T, Westfall P (2011) Multiple comparisons using R. Chapman \& Hall. CRC Press, London

Brouwer R (1963) Some aspects of the equilibrium between overground and underground plant parts. Jaarb IBS 1963: 31-39

Chen S, Lin S, Reinsch T, Loges R, Hasler M, Taube F (2015) Comparison of ingrowth core and sequential soil core methods for estimating belowground net primary production in grass-clover swards. Grass Forage Sci 71:515-528. https://doi.org/10.1111/gfs.12214

Chen S, Lin S, Loges R, Reinsch T, Hasler M, Taube F (2016) Independence of seasonal patterns of root functional traits and rooting strategy of a grass-clover sward from sward age and slurry application. Grass Forage Sci 71:607-621. https://doi.org/10.1111/gfs.12222

Cotrufo MF, Wallenstein MD, Boot CM, Denef K, Paul E (2013) The microbial efficiency-matrix stabilization (MEMS) framework integrates plant litter decomposition with soil organic matter stabilization: do labile plant inputs form stable organic matter? Glob Chang Biol 19:988-995. https://doi. org/10.1111/gcb.12113

Coyette C, Schenk H (2013) Agriculture, forestry and fishery statistics, 2013 edition. Eurostat pocketbooks, European Union, Luxembourg https://doi.org/10.2785/45595

Demyan MS, Ingwersen J, Funkuin YN, Ali RS, Mirzaeitalarposhti R, Rasche F, Poll C, Müller T, Streck T, Kandeler E, Cadisch G (2016) Partitioning of ecosystem respiration in winter wheat and silage maize - modeling seasonal temperature effects. Agric Ecosyst Environ 224: 131-144. https://doi.org/10.1016/j.agee.2016.03.039

Dolman AJ, Valentini R, Groenendijk M, Hendriks D (2008) Flux tower sites, state of the art, and network design. In: Dolman AJ, Valentini R, Freibauer A (eds) The continental-scale greenhouse gas balance in Europe. Springer, New York, pp 215-242

Domanski G, Kuzyakov Y, Siniakina SV, Stahr K (2001) Carbon flows in the rhizosphere of ryegrass (Lolium perenne). J Plant Nutr Soil Sc 164:381-387. https://doi.org/10.1002/15222624(200108)164:4<38

Eshonkulov R, Poyda A, Ingwersen J, Pulatov A, Streck T (2019) Improving the energy balance closure over a winter wheat field by accounting for minor storage terms. Agric For Meteorol 264:283-296. https://doi.org/10.1016/j. agrformet.2018.10.012

Foken T, Göckede M, Mauder M, Mahrt L, Amiro B, Munger W (2004) Post-field data quality control. In: Lee X, Massmann
W, Law B (eds) Handbook of micrometeorology. Atmospheric and oceanographic sciences library, vol 29. Springer, Dordrecht, pp 181-208

Gilmanov TG, Soussana JF, Aires L, Allard V, Ammann C, Balzaralo M, Barcza Z, Bernhofer C, Campbell CL, Cernusa A, Cescatti A, Clifton-Brown J, Dirks BOM, Dore S, Eugster W, Fuhrer J, Gimeno C, Gruenwald T, Haszpra L, Hensen A, Ibrom A, Jacobs AFG, Jones MB, Lanigan B, Laurila T, Lohila A, Manca G, Marcolla B, Nagy Z, Pilegaard K, Pinter K, Pio C, Raschi A, Rogiers N, Sanz MJ, Stefani P, Sutton M, Tuba Z, Valentini R, Williams ML, Wohlfahrt G (2007) Partitioning European grassland net ecosystem $\mathrm{CO}_{2}$ exchange into gross primary productivity and ecosystem respiration using light response function analysis. Agric Ecosyst Environ 121:93-120. https://doi. org/10.1016/j.agee.2006.12.008

Gilmanov TG, Aires L, Barcza Z, Baron VS, Belelli L, Beringer J, Billesbach D, Bonal D, Bradford J, Ceschia E, Cook D, Corradi C, Frank A, Gianelle D, Gimeno C, Gruenwald T, Guo H, Hanan N, Haszpra L, Heilman J, Jacobs A, Jones MB, Johnson DA, Kiely G, Li S, Magliulo V, Moors E, Nagy Z, Nasyrov M, Owensby C, Pinter K, Pio C, Reichstein M, Sanz MJ, Scott R, Soussana JF, Stoy PC, Svejcar T, Tuba Z, Zhou G (2010) Productivity, respiration, and light-response parameters of world grassland and agroecosystems derived from flux-tower measurements. Rangel Ecol Manag 63:1639. https://doi.org/10.2111/REM-D-09-00072.1

HBU (1998) Handbook of soil analyses (HBU), soil quality determination of dry bulk density. Beuth Verlag $\mathrm{GmbH}$, Berlin

Hopkins A (2000) Grass: its production \& utilization. Blackwell Science Ltd., Oxford

Hütsch BW, Augustin J, Merbach W (2002) Plant rhizodeposition - an important source for carbon turnover in soils. J Plant Nutr Soil Sc 165:397-407. https://doi.org/10.1002/1522-2624 (200208)165:4<397::AID-JPLN397>3.0.CO;2-C

James JJ, Ziegenhagen L, Aanderud ZT (2010) Exploitation of nutrient-rich soil patches by invasive annual and native perennial grasses. Invas Plant Sci Mana 3:169-177. https://doi. org/10.1614/IPSM-D-09-00033.1

Jones MB, Donelly A (2004) Carbon sequestration in temperate grassland ecosystems and the influence of management, climate and elevated $\mathrm{CO}_{2}$. New Phytol 164:423-439. https://doi.org/10.1111/j.1469-8137.2004.01201.x

Kim MK, Henry HAL (2013) Net ecosystem $\mathrm{CO}_{2}$ exchange and plant biomass responses to warming and $\mathrm{N}$ addition in a grass-dominated system during two years of net $\mathrm{CO}_{2}$ efflux. Plant Soil 371:409-421. https://doi.org/10.1007/s11104013-1705-1

Klapp E, Stählin A (1936) Standorte, Pflanzengesellschaften und Leistungen des Grünlandes. Eugen Ulmer, Stuttgart

Kutsch WL, Aubinet M, Buchmann N, Smith P, Osborne B, Eugster W, Wattenbach M, Schrumpf M, Schulze ED, Tomelleri E, Ceschia E, Bernhofer C, Béziat P, Carrara A, Di Tommasi P, Grünwald T, Jones M, Magliulo V, Marloie O, Moureaux C, Olioso A, Sanz MJ, Saunders M, Søgaard H, Ziegler W (2010) The net biome production of full crop rotations in Europe. Agric Ecosyst Environ 139:336-345. https://doi.org/10.1016/j.agee.2010.07.016

Kuzyakov Y, Ehrensberger H, Stahr K (2001) Carbon partitioning and below-ground translocation by Lolium perenne. Soil Biol 
Biochem 33:61-74. https://doi.org/10.1016/S0038-0717(00 )00115-2

Laird NM, Ware JH (1982) Random-effects models for longitudinal data. Biometrics 38:963-974. https://doi.org/10.2307 12529876

Li J, Lin S, Taube F, Pan Q, Dittert K (2011) Above and belowground net primary productivity of grassland influenced by supplemental water and nitrogen in Inner Mongolia. Plant Soil 340:253-264. https://doi.org/10.1007/s11104-0100612-y

Lloyd J, Taylor JA (1994) On the temperature dependence of soil respiration. Funct Ecol 8:315-323. https://doi.org/10.2307 12389824

Loges R, Bunne I, Reinsch T, Malisch C, Kluß C, Herrmann A, Taube F (2018) Forage production in rotational systems generates similar yields compared to maize monocultures but improves soil carbon stocks. Eur J Agron 97:11-19. https://doi.org/10.1016/j.eja.2018.04.010

Lorenz RJ, Rogler GA (1967) Grazing and fertilization affect root development of range grasses. J Range Manag 20:129-132. https://doi.org/10.2307/3895790

Manzoni S, Vico G, Katul G, Palmroth S, Jackson RB, Porporato A (2013) Hydraulic limits on maximum plant transpiration and the emergence of the safety-efficiency trade-off. New Phytol 198:169-178. https://doi.org/10.1111/nph.12126

Mauder M, Cuntz M, Drüe C, Graf A, Rebmann C, Schmid HP, Schmidt M, Steinbrecher R (2013) A strategy for quality and uncertainty assessment of long-term eddy-covariance measurements. Agric For Meteorol 169:122-135. https://doi. org/10.1016/j.agrformet.2012.09.006

Moore CJ (1986) Frequency response corrections for eddy correlation systems. Bound-Layer Meteorol 37:17-35. https://doi. org/10.1007/BF00122754

Pausch J, Kuzyakov Y (2018) Carbon input by roots into the soil: quantification of rhizodeposition from root to ecosystem scale. Glob Chang Biol 24:1-12. https://doi.org/10.1111 /gcb. 13850

Peichl M, Leahy P, Kiely G (2011) Six-year stable uptake of carbon dioxide in intensively managed humid temperate grassland. Ecosystems 14:112-126. https://doi.org/10.1007 /s10021-010-9398-2

Poeplau C, Don A, Vesterdal L, Leifeld J, van Wesemael B, Schumacher J, Gensior A (2011) Temporal dynamics of soil organic carbon after land-use change in the temperate zone carbon response functions as a model approach. Glob Chang Biol 17:2415-2427. https://doi.org/10.1111/j.13652486.2011.02408.x

Powlson DS, Jenkinson DS, Johnston AE, Poulton PR, Glendining MJ, Goulding KWT (2010) Comments on "Synthetic Nitrogen Fertilizers Deplete Soil Nitrogen: A Global Dilemma for Sustainable Cereal Production," by RL Mulvaney, SA Khan, and TR Ellsworth in the Journal of Environmental Quality 2009 38:2295-2314. J Environ Qual 39:749-752. https://doi.org/10.2134/jeq2010.0001le

Poyda A, Reinsch T, Kluß C, Loges R, Taube F (2016) Greenhouse gas emissions from fen soils used for forage production in northern Germany. Biogeosciences 13:52215244. https://doi.org/10.5194/bg-13-5221-2016

Poyda A, Wizemann H-D, Ingwersen J, Eshonkulov R, Högy P, Demyan MS, Kremer P, Wulfmeyer V, Streck T (2019) Carbon fluxes and budgets of intensive crop rotations in two regional climates of Southwest Germany. Agric Ecosyst Environ 276:31-46. https://doi.org/10.1016/j. agee.2019.02.011

R Core Team (2019) R: A language and environment for statistical computing. R Foundation for Statistical Computing, Vienna. Available via DIALOG. https://www.R-project.org/

Ravenek JM, Mommer L, Visser EJW, van Ruijven J, van der Paauw JW, Smit-Tiekstra A, de Caluwe H, de Kroon H (2016) Linking root traits and competitive success in grassland species. Plant Soil 407:39-53. https://doi.org/10.1007 /s11104-016-2843-z

Reichstein M, Falge E, Baldocchi D, Papale D, Aubinet M, Berbigier P, Bernhofer C, Buchmann N, Gilmanov T, Granier A, Grünwald T, Havránková K, Ilvesniemi H, Janous D, Knohl A, Laurila T, Lohila A, Loustau D, Matteucci G, Meyers T, Miglietta F, Ourcival J-M, Pumpanen J, Rambal S, Rotenberg E, Sanz M, Tenhunen J, Seufert G, Vaccari F, Vesala T, Yakir D, Valentini R (2005) On the separation of net ecosystem exchange into assimilation and ecosystem respiration: review and improved algorithm. Glob Chang Biol 11:1424-1439. https://doi. org/10.1111/j.1365-2486.2005.001002.x

Remus R, Augustin J (2016) Dynamic linking of ${ }^{14} \mathrm{C}$ partitioning with shoot growth allows a precise determination of plantderived C input to soil. Plant Soil 408:493-513. https://doi. org/10.1007/s11104-016-3006-y

Riederer M, Pausch J, Kuzyakov Y, Foken T (2015) Partitioning $\mathrm{NEE}$ for absolute $\mathrm{C}$ input into various ecosystem pools by combining results from eddy-covariance, atmospheric flux partitioning and ${ }^{13} \mathrm{CO}_{2}$ pulse labeling. Plant Soil 390:61-76. https://doi.org/10.1007/s11104-014-2371-7

Saliendra NZ, Liebig MA, Kronberg SL (2018) Carbon use efficiency of hayed alfalfa and grass pastures in a semiarid environment. Ecosphere 9:e02147. https://doi.org/10.1002 lecs 2.2147

Schaap MG, Leij FJ, van Genuchten MT (2001) Rosetta: a computer program for estimating soil hydraulic parameters with hierarchical pedotransfer functions. J Hydrol 251:163-176. https://doi.org/10.1016/S0022-1694(01)00466-8

Schmidt M, Reichenau TG, Fiener P, Schneider K (2012) The carbon budget of a winter wheat field: an eddy covariance analysis of seasonal and inter-annual variability. Agric For Meteorol 165:114-126. https://doi.org/10.1016/j. agrformet.2012.05.012

Schotanus P, Nieuwstadt FTM, De Bruin HAR (1983) Temperature measurement with a sonic anemometer and its application to heat and moisture fluxes. Bound-Layer Meteorol 26:81-93. https://doi.org/10.1007/BF00164332

Six J, Paustian K (2014) Aggregate-associated soil organic matter as an ecosystem property and a measurement tool. Soil Biol Biochem 68:A4-A9. https://doi.org/10.1016/j. soilbio.2013.06.014

Skiba U, Drewer J, Tang YS, van Dijk N, Helfter C, Nemitz E, Famulari D, Cape JN, Jones SK, Twigg M, Pihlatie M, Vesala T, Larsen KS, Carter MS, Ambus P, Ibrom A, Beier C, Hensen A, Frumau A, Erisman JW, Brüggemann N, Gasche R, Butterbach-Bahl K, Neftel A, Spirig C, Horvath L, Freibauer A, Cellier P, Laville P, Loubet B, Magliulo E, Bertolini T, Seufert G, Andersson M, Manca G, Laurila T, Aurela M, Lohila A, Zechmeister-Boltenstern S, Kitzler B, Schaufler B, Siemens J, Kindler R, Flechard C, Sutton MA 
(2009) Biosphere-atmosphere exchange of reactive nitrogen and greenhouse gases at the NitroEurope core flux measurement sites: measurement strategy and first data sets. Agric Ecosyst Environ 133:139-149. https://doi.org/10.1016/j. agee.2009.05.018

Skinner RH (2008) High biomass removal limits carbon sequestration potential of mature temperate pastures. J Environ Qual 37:1319-1326. https://doi.org/10.2134/jeq2007.0263

Skinner RH (2013) Nitrogen fertilization effects on pasture photosynthesis, respiration, and ecosystem carbon content. Agric Ecosyst Environ 172:35-41. https://doi.org/10.1016/j. agee.2013.04.005

Smith P, Martino D, Cai Z, Gwary D, Janzen H, Kumar P, McCarl B, Ogle S, O'Mara F, Rice C, Scholes B, Sirotenko O, Howden M, McAllister T, Pan G, Romanenkov V, Schneider U, Towprayoon S, Wattenbach M, Smith J (2008) Greenhouse gas mitigation in agriculture. Philos T Roy Soc B 363:789-813. https://doi.org/10.1098 /rstb.2007.2184

Soder KJ, Sanderson MA, Stack JL, Muller LD (2006) Intake and performance of lactating cows grazing diverse forage mixtures. J Dairy Sci 89:2158-2167. https://doi.org/10.3168/jds. S0022-0302(06)72286-X

Soussana J-F, Tallec T, Blanfort V (2010) Mitigating the greenhouse gas balance of ruminant production systems through carbon sequestration in grasslands. Animal 4:34-350. https://doi.org/10.1017/S1751731109990784

Springob G, Kirchmann H (2002) C-rich sandy Ap horizons of specific historical land-use contain large fractions of refractory organic matter. Soil Biol Biochem 34:1571-1581. https://doi.org/10.1016/S0038-0717(02)00127-X

Steingrobe B, Schmid H, Claassen N (2000) The use of the ingrowth core method for measuring root production of arable crops - influence of soil conditions inside the ingrowth core on root growth. J Plant Nutr Soil Sci 163:617-622. https://doi.org/10.1002/1522-2624(200012)163:6<617 ::AID-JPLN617>3.0.CO;2-0

Tennant D (1975) A test of a modified line intersect method of estimating root length. J Ecol 63:995-1001. https://doi. org/10.2307/2258617

VDLUFA (2018) Neue Empfehlungen des VDLUFA für die PDüngung. VDLUFA Mitteilungen 02/2018. VDLUFA, Speyer
VDLUFA (1991) Bestimmung von Bodenazidität und Kalkzustand. In: Methodenbuch Band I: Die Untersuchung von Böden. VDLUFA, Speyer

Verbeke G, Molenberghs G (2000) Linear mixed models for longitudinal data. Springer, New York

Vickers D, Mahrt L (1997) Quality control and flux sampling problems for tower and aircraft data. J Atmos Ocean Technol 14:512-526. https://doi.org/10.1175/1520-0426 (1997)014<0512:QCAFSP >2.0.CO;2

Vos C, Jaconi A, Jacobs A, Don A (2018) Hot regions of labile and stable soil organic carbon in Germany - spatial variability and driving factors. Soil 4:153-167. https://doi. org/10.5194/soil-4-153-2018

Waring RH, Landsberg JJ, Williams M (1998) Net primary production of forests: a constant fraction of gross primary production? Tree Physiol 18:129-134. https://doi.org/10.1093 /treephys/18.2.129

Webb EK, Pearman GI, Leuning R (1980) Correction of flux measurements for density effects due to heat and water vapour transfer. Quart J R Met Soc 106:85-100. https://doi. org/10.1002/qj.49710644707

Wilczak JM, Oncley SP, Stage SA (2001) Sonic anemometer tilt correction algorithms. Bound-Layer Meteorol 99:127-150. https://oi.org/10.1023/A:1018966204465

Wohlfahrt G, Hammerle A, Haslwanter A, Bahn M, Tappeiner U, Cernusca A (2008) Seasonal and inter-annual variability of the net ecosystem $\mathrm{CO}_{2}$ exchange of a temperate mountain grassland: effects of weather and management. J Geophys Res 113. https://doi.org/10.1029/2007JD009286

WRB (2015) World reference base for soil resources 2014, update 2015. International soil classification system for naming soils and creating legends for soil maps. World soil resources reports no. 106. FAO, Rome

Wutzler T, Lucas-Moffat A, Migliavacca M, Knauer J, Sickel K, Šigut L, Menzer O, Reichstein M (2018) Basic and extensible post-processing of eddy covariance flux data with REddyProc. Biogeosciences 15:5015-5030. https://doi. org/10.5194/bg-15-5015-2018

Publisher's note Springer Nature remains neutral with regard to jurisdictional claims in published maps and institutional affiliations. 